\title{
W OKOWACH ETNICZNOŚCI? WYBRANE PARTIE ETNOREGIONALNE W SERBII I CHORWACJI (1990-2012)
}

\author{
IN THE GRIP OF ETHNICITY? SELECTED \\ ETHNOREGIONALIST PARTIES IN SERBIA \\ AND CROATIA (1990-2012)
}

\begin{abstract}
In the last twenty years we have been able to observe an increase in the significance of regional and ethnic identities ("reethnification"), and a resultant proliferation of ethnoregional and regional groupings. But although ethnoregionalist parties (ERP) are widespread in both Western and Central and Eastern Europe, there remains surprisingly little literature differentiating between the various kinds of ethnoregionalist parties and dealing with the lack of common definition of this kind of political actors. Some scholars even propose using a broader term - ethnic party. Moreover, over the years many scholars have believed (and some continue to) that their emergence in multicultural societies conjures up the politicisation of ethnic division and - practically inevitably - leads to "ethnic outbidding", threatening to the stability of democracy.

In the first part of the paper, the author deals with the conceptualisation of ethnoregionalist parties, examining the diversifications of their demands and strategies and showing that to gain voters they can invoke a much broader repertoire of strategies than the ethnic outbidding model suggested. The second part of the article is devoted to the problem of opera-
\end{abstract}

Artykuł powstał dzięki wsparciu finansowemu Uniwersytetu Jagiellońskiego w ramach programu SET (Społeczeństwo - Technologie - Środowisko), który wspóffinansuje Unia Europejska.

This article was supported by funding from the Jagiellonian University within the SET project. The project is cofinanced by the European Union.

This is an Open Access article distributed under the terms of the Creative Commons Attribution 3.0 PL License (creativecommons.org/licenses/by/3.0/pl/), which permits redistribution, commercial and non-commercial, provided that the article is properly cited. (C) The Author(s) 2014.

Publisher: Institute of Slavic Studies PAS [Wydawca: Instytut Slawistyki PAN] 
tion of selected ERPs in Serbia and Croatia. The analysis covers Hungarian parties in Serbia and Serbian ones in Croatia. In the concluding remarks, the author tries to point out the main reasons for the changes in their strategy (as well as demands) over time.

Key words: ethnoregionalist parties; ethnic parties; strategies of ethnoregionalist parties; Serbia; Croatia

\section{STRESZCZENIE}

W ostatnich dwóch dekadach możemy obserwować wyraźny wzrost znaczenia tożsamości regionalnych i etnicznych, prowadzący do powstawania coraz większej liczby ugrupowań etnoregionalnych i regionalnych. Mimo to - podobnie jak w przypadku wielu innych, istotnych i aktualnych współcześnie zjawisk społecznych - zdania badaczy w kwestii przyczyn reetnicyzacji systemów partyjnych, funkcjonowania partii etnoregionalnych, ich typów czy relacji z demokracją pozostają podzielone. Celem artykułu jest przybliżenie toczącej się $w$ tym zakresie dyskusji oraz zaprezentowanie na jej tle wstępnych wyników badań dotyczących funkcjonowania wybranych ugrupowań etnoregionalnych w Serbii i Chorwacji. We wnioskach autorka dąży do wskazania głównych powodów zmian w ich strategii, jak też ich postulatów, wraz z upływem czasu.

Stowa kluczowe: partie etnoregionalne; partie etniczne; funkcjonowanie partii w Serbii i Chorwacji

\section{PRZYCZYNY ODRADZAJĄCEJ SIĘ ETNICZNOŚCI}

W ostatnich dwóch dekadach możemy obserwować wyraźny wzrost znaczenia tożsamości regionalnych i etnicznych, prowadzący do powstawania coraz większej liczby ugrupowań etnoregionalnych i regionalnych. Mimo to - podobnie jak w przypadku wielu innych, istotnych i aktualnych współcześnie zjawisk społecznych - zdania badaczy w kwestii przyczyn reetnicyzacji systemów partyjnych, funkcjonowania partii etnoregionalnych, ich typów czy relacji z demokracją pozostają podzielone. Celem artykułu jest przybliżenie toczącej się w tym zakresie dyskusji oraz zaprezentowanie na jej tle wstępnych wyników badań dotyczących funkcjonowania wybranych ugrupowań etnoregionalnych w Serbii i Chorwacji.

Podejmując próby zidentyfikowania przyczyn odpowiedzialnych za odradzanie się etniczności, badacze wskazują na cztery zjawiska. Pierwsi uważają reetnicyzację za formę oporu przeciwko globalizacji (Castells, 2008; von Beyme, 2002), drudzy za następstwo procesu europeizacji, prowadzącego do decentralizacji władzy, a co za tym idzie scedowania części dotychczasowych obowiązków władz centralnych na poziom regionalny czy lokalny (De Winter \& Gomez-Reino Cachafeiro, 2002, ss. 484, 488; Gomez-Reino Cachafeiro, 2008; Gunther, Montero, \& Linz, 2002, s. 5). Trzeci postrzegają ją jako symptom uaktywnienia się nowego wymiaru konfliktu na osi centrum-peryferie. Uważają oni, iż powstawanie partii etnoregionalnych ma związek z procesem określanym przez Clausa 
Offe mianem etnicyzacji polityki, a więc upolityczniania podziałów etnicznych (Offe, 1999, s. 64; Türsan, 1998, s. 3). Według badań z 1985 roku na świecie funkcjonowało 589 grup etnicznych i aż 8 tysięcy języków (Nielsen, 1985, s. 33). Niespełna dwie dekady później James D. Faron doliczył się już 820 grup etnicznych i etnoreligijnych (Faron, 2003, s. 16). Powyższe dane w opinii badaczy świadczą o postępującej reetnicyzacji (czasem wręcz ocierającej się o trybalizm) ${ }^{1}$. I choć afirmacja etnicznych tożsamości sama w sobie niekoniecznie musi być niebezpieczna, jednak - według Huri Tűrsana - jej połączenie z nacjonalistycznymi sentymentami może posłużyć do manipulacji i "skonstruowania bomby zegarowej" (Türsan, 1998, s. 2). Z kolei czwartą grupę stanowią badacze, wedle których tworzenie ugrupowań etnoregionalnych stanowi szczególną formę protestu przeciwko zbyt silnej pozycji władz centralnych (Dandoy, 2010).

\section{PARTIE ETNOREGIONALNE CZY ETNICZNE?}

Mimo wzmożonego zainteresowania ich genezą, partie etnoregionalne (ERP - Ethnoregionalist Parties) nie doczekały się jeszcze jednej, powszechnie uznanej definicji. Zwykle badacze zwracają uwage na dwie cechy takich formacji: ich ekskluzywistyczny charakter (czego przyczyn można upatrywać w polityzacji etniczności) i żądanie reorganizacji istniejącej struktury stosunków władzy. Jak skonstatował Túrsan, łączą je żądania uznania etnicznej odrębności reprezentowanej przez nie grupy z pewnymi roszczeniami terytorialnymi (Türsan, 1998, s. 5). Mianem partii etnoregionalnych określa się więc ugrupowania reprezentujące terytorialnie skoncentrowane mniejszości (czyli operujące na poziomie niższym niż państwowy), domagające się od władz centralnych zapewnienia większego zakresu autonomii kulturowej bądź terytorialnej (De Winter, 1998, s. 204; Horowitz, 1985, s. 291; Müller-Rommel 1998, s. 19; Strmiska, 2003; Türsan, 1998, s. 5), co je odróżnia od partii regionalnych, które - choć również funkcjonują na szczeblu subpaństwowym - niekoniecznie muszą reprezentować mniejszości etniczne (Strmiska, 2002, s. 2) czy religijne (Brancati, 2008, s. 138). Dawn Brancati uważa, iż zachętą do tworzenia partii regionalnych jest postępujący proces politycznej decentralizacji, rozumianej jako „decentralizacja szczebla podejmowania decyzji politycznych" (Brancati, 2008, ss. 136, 138)². Zaś według Regisa Dandoya, regionalizm może mieć naturę czysto geograficzną lub ekonomiczną (Dandoy, 2010, s. 197). Ponadto Dandoy podkreśla, że przyjmując w definicji partii etnoregionalnych za ich główny cel „modyfikację dotychczasowych relacji z państwem”, wykluczamy z ram tej rodziny partyjnej ${ }^{3}$, ugrupowania dla których postulat ów jest wtórny. $\mathrm{Na}$

\section{- ....}

Według Benjamina Barbera obrazowym przykładem nowego trybalizmu jest plan podziału Bośni i Hercegowiny przygotowany w 1993 roku przez Cyrusa Vance'a i Lorda Owena. Według niego przygotowana wówczas mapa "Mnożąc granice i zawężając zasięg wspólnot etnicznych usitowała przedstawić w formie prawnej absurdalną zasadę uznawania prawie każdego bloku w mieście za odrębny naród, a każdego domu za potencjalnego suwerena. To niefortunne rozwiązanie polityczne, tak długo sankcjonowane przez nieszczęsną radę Bezpieczeństwa ONZ, w innych czasach określano by jako sianie anarchii" (Barber, 1997, s. 15).

2 Jednak nie wszyscy badacze podzielają ten pogląd. Daniele Caramani oraz Daniel Bochsler uważają, iż ta zależność, zwłaszcza w państwach Europy Środkowo-Wschodniej wygląda odwrotnie. A więc to nie decentralizacja jest siłą napędową powstawania partii regionalnych, lecz partie regionalne napędzają decentralizację (Bochsler, 2010).

3 Pytanie, czy partie etnoregionalne powinny zostać uznane za odrębną rodzinę partyjna jest żywiołowo dyskutowane w literaturze przedmiotu. Będąca rzeczniczką ich wyodrębnienia Margarita Gomez-Reino podkreśla, iż ich płaszczyzna programowa nie ogranicza się do problemu decentralizacji, ale obejmuje cztery kwestie: samorządność (samozarządzanie), podział na linii lewica-prawica, ustosunkowanie się do integracji europejskiej oraz do wartości postmaterialnych. Zob. Dandoy 2009, 2010; De Winter 1998; De Winter \& GomezReino Cachafeiro, 2002. 
przykład dotyczy to belgijskiej formacji Vlaams Belang (klasyfikowanej jako ERP), której postulaty mają nacjonalistyczną (a często wręcz faszystowską) naturę i są wymierzone w imigrantów. Zaś kwestia reorganizacji struktury władzy odgrywa w jej programie wyraźnie drugorzędną rolę (Dandoy, 2010, s. 198).

Wypada przy tym dodać, iż nie wszystkim badaczom odpowiada powyższa terminologia. Według Kanchan Chandry - przede wszystkim zajmującej się badaniami indyjskiego systemu partyjnego - większą moc eksplanacyjną ma określenie „partia etniczna”, które badaczka stosuje w odniesieniu do wszystkich ugrupowań zabiegających o poparcie jednej, konkretnej grupy etnicznej, nie zważając, czy w danym państwie stanowi ona mniejszość czy też grupę dominującą (Chandra, 2005, s. 236, 2011, s. 151). Z kolei według Johna Ishiyama i Marijki Breuning - również posługujących się terminem partia etniczna - jest on zbyt ogólny i wymaga doprecyzowania (Ishiyama \& Breuning, 2011).

Zresztą nie tylko definicja ERP jest kwestią problematyczną. Choć w artykułach poświęconych partiom etnoregionalnym można odczuć, iż badacze mają świadomość, że nie są one jednorodnym bytem, jednak próby tworzenia typologii wciąż stanowią margines badań nad tego typu ugrupowaniami. Dotychczas podjęło się tego zaledwie kilku politologów. Przy czym - w moim odczuciu - na szczególną uwagę zasługują zwłaszcza prace dwóch autorów. Prekursorem badań komparatystycznych i autorem pierwszej, a zarazem najbardziej znanej, typologii partii etnoregionalnych był Lieven de Winter, który za kryterium dokonanego podziału przyjął stopień radykalizacji ich żądań dotyczących reorganizacji istniejącej struktury władzy (De Winter, 1998, ss. 205-207). Przy czym w jego typologii zauważalny jest wpływ pracy Janusza Bugajskiego ${ }^{4}$. Zaś w ostatnich latach koncepcja De Wintera została zmodyfikowana przez Règisa Dandoya (Dandoy, 2008, 2010).

Według De Wintera łącznie istnieje pięć typów ugrupowań etnoregionalnych, z czego trzy (partie protekcjonistyczne, autonomistyczne i narodowo-federalistyczne) chcą jedynie reorganizacji władzy i zagwarantowania mniejszościom jakiejś formy samorządności, zaś dwa pozostałe typy partii (separatystyczne i irredentystyczne) domagają się odłączenia regionu od państwa, a więc ich żądania mają wyraźnie niepodległościowy charakter. Zaproponowaną przez badacza typologię oraz charakterystykę poszczególnych typów ugrupowań zaprezentowano w tabeli. Ponadto De Winter podkreśla, że ugrupowania etnoregionalne często zmieniają strategię i wytyczone cele, a więc ich przypisanie do poszczególnych typów zazwyczaj ma charakter tymczasowy. Jako przykład podaje fakt, iż większość ruchów etnoregionalnych w Europie Zachodniej (których ważnym postulatem było zwrócenie uwagi na odrębność językową reprezentowanych przez nie grup), uformowała się jako ruchy kulturowo-protekcjonistyczne, jednak z czasem ewoluowały one w formacje autonomistyczne bądź narodowo-federalistyczne. Co więcej, w latach 80. XX wieku takie ugrupowania często odwoływały się do popularnego wówczas hasła „Europy regionów", co według niego było sprytnym fortelem, służącym uniknięciu otwarcie separatystycznych żądań (De Winter, 1998, s. 208). Postulaty tego typu były wówczas zgłaszane nie tylko przez formacje etnoregionalne, a więc reprezentujące mniejszości, ale też stricte regionalne, podkreślające odrębność i wyjątkowość pewnych regionów europejskich (wprawdzie

4 W pracy z 1994 roku, poświęconej polityce etnicznej w szeroko rozumianej Europie Środkowej (obejmującej Bałkany i w znacznym stopniu koncentrującej się właśnie na nich), Bugajski zaprezentował 5 typów takiej polityki: kulturalne ożywienie (cultural revivalism), autonomia polityczna (political autonomism), terytorialne samostanowienie (territorial self-determinism), separatyzm, irredentyzm, których charakterystyka jest dość zbieżna z typami partii etnoregionalnych opisanymi później przez De Wintera. Zresztą Bugajski stwierdzit, iż na bazie tych typów mogą się ukształtować ugrupowania walczące o prawa grup etnicznych. Ponadto - podobnie jak De Winter - zauważył, iż polityka etniczna charakteryzuje się zmiennością priorytetów i strategii. (Bugajski, 1994, ss. XXII-XXIII). 
zwykle o wyraźnie wielokulturowym charakterze). W Chorwacji po takie hasła w latach 90. sięgał Demokratyczny Kongres Istrii - IDS (Istarski demokratski sabor), zaś w Serbii Liga Socjaldemokratów Wojwodiny - LSV (Liga socijaldemokrata Vojvodine). Zresztą oba ugrupowania spotkała z tego powodu ostra krytyka ze strony rządzących wówczas partii: Chorwackiej Wspólnoty Demokratycznej - HDZ (Hrvatska demokratska zajednica) i Socjalistycznej Partii Serbii - SPS (Socijalistička partija Srbije), postulujących ścisłą centralizację władzy, a często też innych relewantnych formacji na tamtejszych scenach politycznych, które oskarżały je o separatyzm, zagrażający integralności państwa.

Tab. 1 Typologia partii etnoregionalnych Lievena de Wintera

1. Partie żądające reorganizacji istniejącej struktury władzy i zwiększenia stopnia autonomii regionów (nie zgłaszające żądań niepodległościowych):

\begin{tabular}{|c|c|}
\hline A. partie protekcjonistyczne & $\begin{array}{l}\text { Uważają iż reprezentowany przez nie segment społeczeństwa } \\
\text { charakteryzuje się wyjątkowymi cechami, dlatego też żądają } \\
\text { uznania odrębności swojej tożsamości kulturowej oraz prawa do } \\
\text { jej rozwijania i ochrony. Najczęściej wysuwane postulaty: } \\
\text { uznanie języka, którym posługuje się dana grupa etniczna za język } \\
\text { urzędowy w danym regionie (choć niektóre ugrupowania akceptu- } \\
\text { ją wprowadzenie zasady dwujęzyczności); } \\
\text { zagwarantowanie specjalnych kwot dla przedstawicieli mniej- } \\
\text { szości przy zatrudnianiu w państwowych urzędach, co ma służyć } \\
\text { zapobieganiu dyskryminacji etnicznej. }\end{array}$ \\
\hline B. partie autonomistyczne & $\begin{array}{l}\text { Domagają się podziału kompetencji między władze centralne } \\
\text { i regionalne. Przy czym uważają (i podkreślają), iż reprezentowana } \\
\text { przez nie wspólnota etnokulturowa powinna być przez państwo } \\
\text { traktowana w sposób szczególny, inaczej niż pozostałe wspólnoty } \\
\text { mieszkające na terytorium danego państwa (co wyraźnie odróżnia } \\
\text { je od kolejnego typu - partii narodowo-federalistycznych). Doma- } \\
\text { gają się zwiększenia uprawnień władz regionalnych. W ich opinii } \\
\text { rząd krajowy powinien być odpowiedzialny jedynie za politykę } \\
\text { monetarną, obronną i zagraniczną. }\end{array}$ \\
\hline $\begin{array}{l}\text { C. partie } \\
\text { narodowo-federalistyczne }\end{array}$ & $\begin{array}{l}\text { Ich najważniejszym postulatem jest przekształcenie państw uni- } \\
\text { tarnych w federalne, co ma zapewnić większy stopień autonomii } \\
\text { regionom. }\end{array}$ \\
\hline \multicolumn{2}{|c|}{ 2. Ugrupowania domagające się separacji (odłączenia) regionu: } \\
\hline D. partie niepodległościowe & $\begin{array}{l}\text { Domagają się pełnej niepodległości regionu na tereniu które- } \\
\text { go funkcjonują. Część tego typu ugrupowań jest przychylnie } \\
\text { nastawiona do idei "Europy regionów", inne odrzucają możliwość } \\
\text { uznania jakiejkolwiek władzy na poziomie ponadnarodowym. } \\
\text { Nieliczne partie niepodległościowe są gotowe do użycia prze- } \\
\text { mocy i podejmowania akcji terrorystycznych, w celu osiągnięcia } \\
\text { suwerenności. }\end{array}$ \\
\hline E. partie irredentystyczne & $\begin{array}{l}\text { Nie tylko postulują oddzielenie się i uzyskanie pełnej suwerenno- } \\
\text { ści, ale chcą się przyłączyć do państwa o podobnej tożsamości } \\
\text { kulturowej. Postulaty irredentystyczne zwykle zgłaszają mniejszo- } \\
\text { ści zamieszkujące tereny przy granicy z państwem macierzystym, } \\
\text { a ich żądania przybierają na sile w okresie eskalacji kryzysów } \\
\text { międzynarodowych. }\end{array}$ \\
\hline
\end{tabular}

Opracowanie własne na podstawie: De Winter, 1998, ss. 205-207.

Z kolei Dandoy, również biorąc za kryterium podziału radykalizm żądań formacji etnoregionalnych, wyodrębnit ich trzy gtówne typy, z których każdy dzieli się na kilka podtypów. Partie o niskiej intensywności żądań nazwał protekcjonistycznymi, zaś ich podtypy określił mianem formacji konserwatywnych i partycypujących (participationist). Drugim typem są 
partie nazwane przez niego decentralistycznymi (wprawdzie zgłaszające umiarkowanie łagodne postulaty, jednak stanowiące wyzwanie dla wewnętrznego porządku), do których zaliczył ugrupowania autonomistyczne, federalistyczme i konfederalistyczne. Ostatni, trzeci, typ stanowią partie secesjonistyczne, których apel charakteryzuje się największym stopniem radykalizmu, a ich funkcjonowanie stanowi wyzwanie także dla międzynarodowego porządku. Za podtypy partii secesjonistycznych Dandoy uznał ugrupowania niepodległościowe, irredentystyczne oraz ratachistyczne. Wyodrębnienie partii ratachistycznych - jako odrębnego podtypu ugrupowań secesjonistycznych - oraz ich charakterystykę należy uznać za największy wkład Dandoya w badania nad ERP.

Według badacza irredentyzm można określić mianem „polityki mającej na celu odzyskanie utraconych terytoriów" oraz połączenie z pobratymcami, należącymi do tej samej grupy etnokulturowej, z którymi rozdziela ich granica państwowa (Dandoy, 2010, s. 212). Partie irredentystyczne żądają więc nie tylko niepodległości regionu, na terenie którego działają, ale też aneksji do nowo tworzonego organizmu państwowego obszarów formalnie leżących na terenie innego państwa. Świetnym przykładem takiego typu postulatów były kilkukrotnie, od końca lat 90. powracające żądania Partii Akcji Demokratycznej Sandżaku - SDA (Stranka demokratske akcije Sandžaka) - funkcjonującej w serbskiej części tego regionu - utworzenia niepodległego Sandżaku, w skład którego wchodziłyby zarówno tereny serbskie, jak i czarnogórskie. Dla odróżnienia partie ratachistyczne nie dążą do pełnej suwerenności, nie są też zainteresowane aneksją terytoriów należących do sąsiednich państw, a wręcz odwrotnie. Domagają się one przyłączenia regionu, w którym działają do innego, niepodległego państwa. Przy czym Dandoy podkreśla, iż tego typu partie były dotychczas błędnie klasyfikowane $w$ literaturze jako formacje irredentystyczne (Dandoy, 2008, ss. 9-10, 2010, s. 213). Książkowym przykładem takiego ugrupowania, od którego zresztą bierze ono swoją nazwę, jest ruch społeczno-polityczny we frankofońskiej części Belgii, który domaga się jej przyłączenia do Francji. Co warte podkreślenia, według Dandoya tego typu postulaty częściej charakteryzują ugrupowania wywodzące się z biednych regionów. Albowiem, jak słusznie zauważa, niepodległość wymaga sporych nakładów finansowych. Dobrym przykładem znowu mogą być żądania sandżackiej SDA, tym razem z początku lat 90., gdy jej lider Sulejman Ugljanin postulował przyłączenie Sandżaku do Bośni. Szerzej typologię Dandoya zaprezentowano w Tab. 2.

Tab. 2 Typologia partii etnoregionalnych Regisa Dandoya

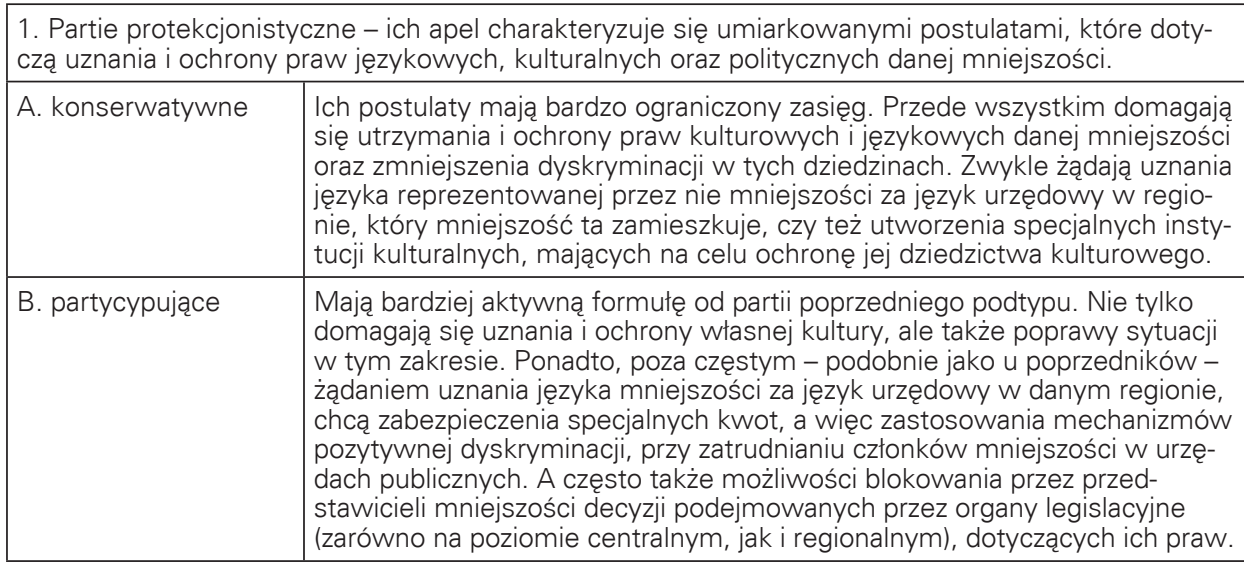


2. Partie decentralistyczne - choć ich postulaty wciąż są umiarkowane, stanowią wyzwanie dla istniejących struktur władzy. Domagają się bowiem ich reorganizacji oraz przyznania większych uprawnień władzom regionalnym. Poszczególne podtypy wyraźnie różnią się zakresem żądań.

\begin{tabular}{|l|l|}
\hline C. autonomistyczne & $\begin{array}{l}\text { Domagają się autonomii regionu, który reprezentują, podkreślając jego } \\
\text { wyjątkowość na tle innych regionów czy jednostek podziału terytorialnego. } \\
\text { Ich dyskurs charakteryzuje się więc bardzo specyficznym rozumieniem } \\
\text { decentralizacji władzy, jako procesu, na którym skorzysta tylko i wyłącznie } \\
\text { reprezentowany przez nie region. Jeśli ów region posiada już autonomię, } \\
\text { domagają się wzmocnienia i zwiększenia uprawnień władz regionalnych. }\end{array}$ \\
\hline D. federalistyczne & $\begin{array}{l}\text { Domagają się decentralizacji władzy, podkreślając, iż winna być ona } \\
\text { dzielona między poziom centralny i regionalny, którego uprawnienia należy } \\
\text { wzmacniać. Przy czym ich postulaty nie odnoszą się, jak w poprzednim } \\
\text { przypadku, do jednego, konkretnego regionu, ale zakładają, iż wszystkie } \\
\text { regiony powinny uzyskać jednakowe kompetencje. }\end{array}$ \\
\hline E. konfederalistyczne & $\begin{array}{l}\text { W przypadku tego podtypu partii to one decydują, jakie uprawnienia } \\
\text { regiony powinny delegować na rzecz władz centralnych. Główną cechą, } \\
\text { odróżniającą je od partii federalistycznych, jest założenie, iż suwerenność } \\
\text { przynależy regionom oraz - co ma z tym związek - zastosowanie strategii } \\
\text { oddolnego delegowania kompetencji. }\end{array}$ \\
\hline
\end{tabular}

3. Partie secesjonistyczne - za główny cel obrały oderwanie regionu zamieszkiwanego przez reprezentowana przez nie mniejszość od „państwa-gospodarza” (na terenie którego obecnie funkcjonują) i utworzenie niezależnego państwa, a więc „zmianę właściciela terytorium” (Dandoy, 2010, s. 210). Przy czym propagują one kilka różniących się rozwiązań w tym zakresie. Partie te stanowią poważne wyzwanie nie tylko dla wewnętrznego, ale też międzynarodowego porządku, bowiem domagają się redefinicji granic.

\begin{tabular}{|l|l|}
\hline F. niepodległościowe & $\begin{array}{l}\text { Głównym postulatem partii niepodległościowych jest utworzenie suweren- } \\
\text { nego państwa, którego podstawą będzie "oderwany" region lub regiony } \\
\text { (np. koncepcja utworzenia Wielkiej Katalonii, obejmującej regiony Walencji } \\
\text { i Balearów). }\end{array}$ \\
\hline G. irredentystyczne & $\begin{array}{l}\text { Nie tylko postulują utworzenie suwerennego państwa, ale również włą- } \\
\text { czenie do niego (aneksję) obszarów znajdujących się na terenie innego } \\
\text { państwa zamieszkiwanego przez tę samą (lub mającą podobne cechy) gru- } \\
\text { pę etnokulturową. Tego typu żądania charakterystyczne są dla mniejszości } \\
\text { mieszkających na terenach przygranicznych, których obszar został (np. } \\
\text { W wyniku wojen bądź porozumień pokojowych) podzielony między dwa } \\
\text { odrębne organizmy państwowe. }\end{array}$ \\
\hline H. ratachistyczne & $\begin{array}{l}\text { Postulują oderwanie danego regionu od dotychczasowego państwa oraz } \\
\text { jego przyłączenie do państwa sąsiedniego. Ządania tego typu przede } \\
\text { Wszystkim są charakterystyczne dla mało liczebnych mniejszości, żyjących } \\
\text { W ubogich regionach przygranicznych. }\end{array}$ \\
\hline
\end{tabular}

Opracowanie własne na podstawie: Dandoy 2008, ss. 6-10, 2010, ss. 206-214.

\section{STRATEGIE PARTII ETNOREGIONALNYCH}

Partie etnoregionalne (czy szerzej etniczne) stały się przedmiotem wzmożonej refleksji naukowej w latach 70. Przez ponad 20 lat w badaniach tego typu ugrupowań dominował pogląd, iż konkurencja etniczna podczas rywalizacji wyborczej stanowi poważne wyzwanie, a nawet zagrożenie, dla przetrwania demokratycznego reżimu. Ówcześni badacze stali na stanowisku, iż wprowadzenie rywalizacyjnych wyborów w społecznościach zróżnicowanych etnicznie właściwie nieuchronnie prowadzi do etnicyzacji elektoratów oraz wystąpienia efektu przelicytowania etnicznego (ethnic outbidding) (Horowitz, 1985; Rabushka \& Shepsle, 1972), oznaczającego sytuację, gdy podczas „wewnątrzetnicznej” rywalizacji o głosy wyborców, partie zaostrzają dyskurs, w celu zwiększenia swojej atrakcyjności. Przyjęcie umiarkowanej strategii było możliwe i opłacalne dla partii wyłącznie wów- 
czas, gdy etniczność nie stanowiła kwestii dominującej. Jak podkreślali Alvin Rabushka i Kenneth Shepsle, kiedy etniczności raz uda się dojść do głosu, trudno ją potem usunąć w cień politycznego dyskursu (Rabushka \& Shepsle, 1972, s. 86). Według badaczy, jeśli jednak nie jest ona kwestią drugorzędną, przyjęcie strategii przelicytowania etnicznego właściwie staje się nieuniknione, w ramach ERP zawsze bowiem znajdą się przedsiębiorcy polityczni (partie lub konkretni politycy) gotowi prowokować ugrupowania umiarkowane poprzez nagłaśnianie kwestii etnicznych (i manipulację nimi), aby w ten sposób zdobyć przewage nad nimi (Rabushka \& Shepsle, 1972, ss. 91-92). Dlatego też, dostrzegając zagrożenie, jakie niesie ze sobą nadmierne upolitycznienie etnicznych podziałów, inny uznany badacz systemów politycznych - Arend Lijphart stworzył koncepcję demokracji konsensualnej, której cechą charakterystyczną jest dążenie do ograniczenia rywalizacji w społeczeństwach wielokulturowych (Lijphart, 1977; Bartolini, 2000, s. 40).

Wypada spytać o źródło powyższych obaw. W starszych badaniach dość powszechne było założenie o homogeniczności grupowych poglądów i ich radykalizmie, na co zwracali uwage w swojej pracy przede wszystkim Rabushka i Shepsle. z kolei Donald Horowitz podkreślał, iż partie etniczne próbują się kierować niezgodnymi interesami grup, które je wspierają, co często prowadzi do tego, iż ich program i działania charakteryzują się głęboką niespójnością (Horowitz, 1985, s. 297). Ponadto bagatelizowano fakt, iż modele te powstały w oparciu o badania przeprowadzone głównie w państwach afrykańskich, charakteryzujących się istnieniem tzw. „ściśle etnicznie zsegmentowanych rynków wyborczych" (a więc rywalizacja wyborcza przebiega tam wyłącznie według podziałów etnicznych). Często istnieją w nich dwie grupy etniczne, z których jedna (mniejsza) permanentnie przegrywa wybory, a ponieważ rywalizacja przebiega wzdłuż osi podziałów etnicznych, raczej nie ma szans, by jej sytuacja w przyszłości uległa zmianie, co może dodatkowo wzmagać radykalizację rywalizacji (Horowitz \& Long, 2006, s. 3). Jak zauważył Horowitz, wygrywające partie mają jednak pewien wachlarz możliwości, z których mogą skorzystać, by nie doprowadzić do radykalizacji działań ugrupowań przegrywających (Horowitz \& Long, 2006, ss. 4-5) .

W nowszych pracach coraz częściej zwraca się uwagę, iż partie etniczne mogą skorzystać z bardziej umiarkowanego repertuaru strategii, co miało związek z zakwestionowaniem poglądu o homogeniczności postaw i oczekiwań etnicznych elektoratów. Badająca partie etniczne w Indiach Kanchan Chandra zwracała uwagę, iż ugrupowania te coraz częściej starają się zamiast podziałów etnicznych nagłaśniać inne, bardziej złożone podziały socjopolityczne, przecinające linię podziałów stricte etnicznych (Chandra, 2005). Również Daniel Bochsler i Edina Szöcsik (2013) oraz John Coakley (2008) stwierdzili, iż partie etnoregionalne, wbrew wciąż dominującemu modelowi etnicznego przelicytowania, coraz częściej starają się przedstawić jako bardziej umiarkowane niż bardziej radykalne. Według Coakleya - badającego strategie dostępne dla ugrupowań dopiero wchodzących na rynek wyborczy w systemie partyjnym opartym na podziałach etnicznych - mają one trzy możliwości, a więc sięgnięcie po strategię:

- przelicytowania etnicznego (ethnic outbiding) - partia w swoim apelu skupia się wyłącznie na podkreślaniu istniejących podziałów etnicznych, starając się przekonać wyborców, iż strategia etnicznego przelicytowania pozostaje najbardziej skuteczną metodą obrony zbiorowych interesów (interesów danej mniejszości);

- zmniejszenia stawki etnicznej (ethnic underbidding) - partia poszukuje bardziej umiarkowanych strategii niż dotychczas funkcjonujące ugrupowania, starając się znaleźć jakieś punkty wspólne dla wyborców różnych grup etnicznych; 
- kontrpropozycji nieetnicznej (non-ethnic counterbidding) - partie odrzucają etnicznie zorientowany apel i skupiają się na innych podziałach socjopoloitycznych, przecinających podziały etniczne.

Ponadto od lat 90. zaczęto też zwracać uwagę, iż przyjmowane przez partie strategie mogą się zmieniać w czasie. Biorąc pod uwagę podmiot apelu partii etnicznych oraz ich pozycję dotyczącą kwestii etnicznych, Christine Zuber zaproponowała nowy model badawczy, który zaprezentowano w Tab. 3.

Tab. 3 Strategie partii etnicznych

\begin{tabular}{|c|c|c|c|}
\hline & \multicolumn{3}{|c|}{ Kryteria pozycjonowania } \\
\hline Typ apelu: & Bardziej umiarkowany & Bez zmian & Bardziej radykalny \\
\hline $\begin{array}{l}\text { Wyłączający } \\
\text { (Exclusive) }\end{array}$ & $\begin{array}{l}\text { zmniejszenie stawki } \\
\text { etnicznej (ethnic under- } \\
\text { bidding) - partyjne apele } \\
\text { kierowane są wyłącznie } \\
\text { do jednej grupy etnicznej, } \\
\text { treść apelu jest jednak } \\
\text { bardziej umiarkowana od } \\
\text { apeli pozostałych ugru- } \\
\text { powań chcących zdobyć } \\
\text { głosy tego elektoratu, np. } \\
\text { jeśli dotychczas najważ- } \\
\text { niejsza partia etnoregio- } \\
\text { nalna żądała autonomii } \\
\text { terytorialnej, to ta mówi } \\
\text { o autonomii kulturowej. }\end{array}$ & $\begin{array}{l}\text { licytacja statyczna } \\
\text { (static bidding)- partia } \\
\text { utrzymuje zarówno } \\
\text { ekskluzywistyczny apel, } \\
\text { jak i wyjściową pozycję } \\
\text { w kwestiach etnicznych. }\end{array}$ & $\begin{array}{l}\text { przelicytowanie et- } \\
\text { niczne (ethnic outbid- } \\
\text { ding) - partia zwraca się } \\
\text { wyłącznie do jednej grupy } \\
\text { etnicznej, głosząc bardziej } \\
\text { radykalne poglady niż } \\
\text { pozostałe ugrupowania } \\
\text { zabiegające o poparcie } \\
\text { tejże grupy. }\end{array}$ \\
\hline $\begin{array}{l}\text { Niewyłączający } \\
\text { (Non-exclusive) }\end{array}$ & $\begin{array}{l}\text { niedolicytowanie late- } \\
\text { ralne (lateral underbid- } \\
\text { ding) - apel takiej partii } \\
\text { wykracza poza jedną gru- } \\
\text { pe etniczna, jednocześnie } \\
\text { ugrupowanie przesuwa } \\
\text { się w kierunku bardziej } \\
\text { umiarkowanych pozycji } \\
\text { w wymiarze etnicznym. }\end{array}$ & $\begin{array}{l}\text { licytacja lateralna (la- } \\
\text { teral bidding) - partia za- } \\
\text { czyna odwotywać sie do } \\
\text { szerszego elektoratu, nie } \\
\text { zmienia jednak wyjścio- } \\
\text { wego apelu w kwestiach } \\
\text { etnicznych. }\end{array}$ & $\begin{array}{l}\text { przelicytowanie late- } \\
\text { ralne (lateral outbidding) } \\
\text { - partia zaczyna sie } \\
\text { otwierać na wyborców } \\
\text { innych grup, jednocześ- } \\
\text { nie radykalizując poglądy } \\
\text { w kwestiach etnicznych. }\end{array}$ \\
\hline
\end{tabular}

Opracowanie własne na podstawie: C.I. Zuber (2013), Beyond outbidding? Ethnic party strategies in Serbia, Party Politics 19(5), originally published online on 25 July 2011, s. 761.

Zarówno typologia Coakleya, jak i Zuber wydają się bardzo dobrym narzędziem do badania strategii ERP, jednak wstępna analiza działań podejmowanych przez ugrupowania etnoregionalne funkcjonujące w Chorwacji, a zwłaszcza w Serbii (na bazie których Zuber stworzyła swój paradygmat) pokazują, że nie zawierają one pełnego spektrum wykorzystywanych przez nie strategii. Coakley wspomina, iż partie tego typu mogą porzucić postulaty etniczne i zastosować nieetniczną kontrpropozycję, dzięki której próbują zainteresować swoim przekazem szerszy krąg odbiorców. Także dwa typy strategii wskazanych przez Zuber (tj. niedolicytowanie lateralne i licytacja lateralna) dotyczą działań mających na celu poszerzenie elektoratu na wyborców spoza konkretnej grupy etnicznej ${ }^{5}$.

5 Pomijam specyficzny typ apelu, jakim jest przelicytowanie lateralne, albowiem według samej badaczki takie połączenie treści jest raczej hipotetyczną możliwością, gdyż - nawet przy dużym stopniu dobrej woli - trudno uwierzyć, iż byłby on w stanie przyciągnąć "nieetnicznych" wyborców. 
W praktyce istnieje jednak jeszcze jedna, pominięta przez nich możliwość, którą umownie nazwałam nieetnicznym przelicytowaniem. Jest to strategia, po którą sięgają partie etnoregionalne, gdy ich gtównym rywalem nie są inne ugrupowania ERP, lecz któraś z relewantnych w danym kraju/regionie formacji „nieetnicznych”. Przykładem może być spór (swoista licytacja na radykalizm żądań) dwóch partii działających na terenie Wojwodiny: najsilniejszej obecnie formacji reprezentującej mniejszość węgierską - Związku Wojwodińskich Węgrów (Savez vojvođanskih Mađara - SVM) oraz regionalnej Ligi Socjaldemokratów Wojwodiny (Liga socijaldemokrata Vojvodine - LSV). Mimo iż obie działają w tym samym regionie, ich cele zazwyczaj były rozbieżne. SVM domagała się autonomii politycznej i kulturowej tylko i wyłącznie dla mieszkających w tym regionie Węgrów (czasem postulowała utworzenie samorządu etnicznego). Zaś LSV podnosiła żądania autonomii dla całego regionu, a nie tylko dla mniejszości węgierskiej, ostro sprzeciwiając się pomysłom tworzenia przez nią samorządu etnicznego. W 2009 roku SVM, jako jedyna formacja w serbskiej Skupsztinie, głosował przeciwko nowelizacji budżetu krajowego, gdyż nie została w nim zapewniona przewidziana w konstytucji kwota 7\% PKB na wydatki prowincji („Ustav...”, 2006, art. 184). Co warte podkreślenia, deputowani SVM sprzeciwili się polityce koalicyjnego rządu Mirka Cvetkovicia, mimo iż współrządzili wówczas z demokratami w Wojwodinie. LSV wprawdzie również krytykowała kształt nowelizacji, ale nie zdobyła się na taki krok („Čanak (LSV)...”, 2009). Przyjęta przez SVM strategia była wymierzona w wojwodińskich socjaldemokratów i służyła wykreowaniu partii na prawdziwą rzeczniczkę interesów prowincji (w myśl zasady: „czyny nie słowa”). Miało to pomóc SVM w pozyskaniu nieetnicznego elektoratu, a zarazem osłabić pozycję LSV, pokazując wyborcom, iż nie spełnia ona danych im obietnic. W tej sytuacji nie dziwi, iż dotychczas dobre stosunki SVM i DS uległy ochłodzeniu, a w kolejnych wyborach parlamentarnych w 2012 roku kandydaci LSV ponownie znaleźli się na listach firmowanej przez demokratów i ówczesnego prezydenta Borisa Tadicia koalicji "Wybór lepszego życia”. Wprawdzie oba ugrupowania zdobyły w nich po 5 mandatów, jednak porównanie ich rzeczywistej sity i odpowiedź na pytanie, czy strategia SVM okazała się skuteczna, nastręcza pewne trudności. Jak wspomniałam, socjaldemokraci startowali w szerokiej koalicji, a zdobyte mandaty przypadły im na podstawie wcześniejszej umowy. Zaś SVM stanął do wyborczej rywalizacji samodzielnie i jako jedyne ze startujących w niej ugrupowań etnoregionalych uzyskał lepszy wynik niż w poprzednim cyklu wyborczym6.

\section{RAMY INSTYTUCJONALNO-PRAWNE TWORZENIA ORAZ FUNKCJONOWANIE PARTII ETNOREGIONALNYCH W SERBII I CHORWACJI - WPROWADZENIE}

Według spisu ludności przeprowadzonego w 2011 roku członkowie mniejszości narodowych stanowili 16,8\% ludności Serbii (w 2002 r. 14,38\%, a w 1991 r. aż 23\%) i 9,6\%

\footnotetext{
6 W 2008 roku SVM i jego lider Jožef Kasa stanęli na czele koalicji trzech głównych ugrupowań reprezentujących wojwodińskich Węgrów (SVM, DZVM Šandora Pala i DSVM Andraša Agoštona), tzw. Węgierskiej Koalicji. Na mocy zawartej wcześniej umowy, SVM uzyskał 4, czyli de facto wszystkie, zdobyte przez nią mandaty. Przy czym, w 2008 roku na listę Węgierskiej Koalicji głosowało 1,81\% wyborców, zaś cztery lata później SVM samodzielnie uzyskał poparcie 1,75\% wyborców. Wypada wspomnieć, iż w 2008 roku frekwencja wyniosła 61,4\%, zaś 2012 roku była nieco niższa, osiągając poziom 57,89\%.

7 Spisy te nie uwzględniały mniejszości albańskiej mieszkającej na terytorium Kosowa, która od 1989 roku - gdy Slobodan Milošević przeforsował nowelizację ówczesnej serbskiej konstytucji znoszącą faktyczną autonomie prowincji - bojkotowała wszystkie wybory, referenda i spisy ludności organizowane przez rząd w Belgradzie.
} 
Chorwacji (w 2001 r. ich udział wyniósł 7,5 \%, a 10 lat wcześniej 21,9\%). Tym, co łączy oba państwa, przede wszystkim jest znaczący ubytek liczby przedstawicieli mniejszości, do jakiego doszło w okresie między spisami z 1991 i 2001 roku (w przypadku Serbii 2002). Przyczyn tej sytuacji można upatrywać zarówno w migracjach i przesiedleniach, związanych z działaniami wojennymi prowadzonymi na terytorium byłej Jugosławii w latach 90., ale też zmianami deklarowanej przez obywateli przynależności narodowej, co wynikało z silnego upolitycznienia kwestii etnicznych i religijnych w tym okresie oraz obawami przed represjami. Z drugiej zaś strony, nieznaczny wzrost liczby przedstawicieli mniejszości w okresie między kolejnymi spisami 2001/2002-2011, może potwierdzać hipotezę o rosnącej reetnicyzacji. Jak obrazowo skonstatował Manuel Castells, wszechobecna globalizacja niszczy wyjątkowość społeczeństw (grup, regionów), wywołując ich opór, dlatego „,kiedy świat staje się zbyt wielki, by móc go kontrolować, aktorzy społeczni starają się zmniejszyć go z powrotem do swych wymiarów i zasięgu". A jedną z form „obrony" stanowi proces reetnicyzacji i związane z nim tworzenie ruchów lub partii etnonarodowych, o czym wspominałam (Castells, 2008, s. 73).

Najliczniejszą grupę spośród mniejszości w Serbii stanowią Węgrzy, których udział procentowy w strukturze ludności wynosi 3,53\% (2002 r. - 3,91\%), następnie Romowie 2,05\% (2002 r. - 1,44), Boszniacy 2,02\%, (2002 r. - 1,82\%), Chorwaci 0,81\% (2002 r. 0,94\%) i Albańczycy 0,08\% (2002 r. - 0,82\%) (Popis stanovništva Republike Srbije 2002, 2002; "Popis stanovništva Republike Srbije 2011”, 2011). Wyraźna jest regionalna koncentracja mniejszości. O ile w Centralnej Serbii etniczni Serbowie stanowią blisko 90\% ogółu mieszkańców, to w Wojwodinie ich udział spada do ok. 2/3 populacji, zaś najliczniejszą z wojwodińskich mniejszości stanowią Węrzy, których udział wynosi 13,1\% (2002 r. - 14,28\%). Jako główne przyczyny spadku odsetka ludności węgierskiej wskazuje się przede wszystkim na niski przyrost naturalny wśród jej członków, migracje (zwłaszcza od wejścia Węgier do UE w 2004 roku) oraz jej asymilację („Broj Mađara...”, 2012).

W Chorwacji, mimo znaczącego ubytku, najliczniejszą mniejszość wciąż stanowią Serbowie, których udział w strukturze ludności wynosi 4,5\% (w 1991 r. - 12,2\%). Drugą pod względem liczebności jest mniejszość boszniacka (0,7\% mieszkańców). W przypadku pozostałych mniejszości, odsetek ich przedstawicieli nie przekracza 0,5\%.

Ciekawe są dane dotyczące funkcjonowania ugrupowań etnoregionalnych. Z rejestru partii, prowadzonego przez serbskie Ministerstwo Administracji Publicznej i Samorządu Lokalnego, wynika, iż 51 spośród 91 partii politycznych zarejestrowanych w Serbii do grudnia 2012 roku (zgodnie z wymogami znowelizowanej Ustawy o partiach politycznych

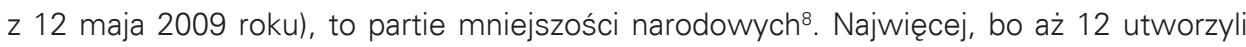
Boszniacy ${ }^{9}$ - choć w liczbach bezwzględnych stanowią oni zaledwie 145278 serbskich obywateli. Po sześć partii zarejestrowały mniejszość węgierska, albańska i romska, cztery wołoska, trzy Bułgarzy i Bunjewcy. Po dwa ugrupowania reprezentują Chorwatów, Słowaków, Rumunów i Rusinów, po jednej partii założyli przedstawiciele Czarnogórców, Goran i Macedończyków. Natomiast w Chorwacji spośród 123 znajdujących się w 2012 roku

$\cdots$

Przyjęta 12 maja 2009 roku nowelizacja Ustawy o partiach politycznych nałożyła na partie obowiązek ponownej rejestracji i spełnienia dodatkowych wymogów formalnych. Najbardziej krytykowano konieczność uzyskania przez partie 10 tys. podpisów poparcia, podczas gdy dotychczas wystarczało ich 100. W przypadku partii mniejszości narodowych ten wymóg jednak złagodzono. Zostały one zobligowane do zebrania tysiąca podpisów, co niewątpliwie wpłynęło na wyraźny wzrost ich liczby. Zob. "Zakon o političkim strankama", 2009, Art. 8-9; „Petsto stranaka...”, 2010.

9 Etnonim Boszniak odnosi się do mieszkańców Bośni i Hercegowiny wyznania muzułmańskiego lod lat 70. określanych mianem Muzułmanów, pisanych wielką literą). Pozostałych mieszkańców kraju, wyznawców innych konfesji, nazywa się Bośniakami. Szerzej o genezie tej nazwy i związanych w nią problemach pisałam w odrębnym artykule. Mikucka-Wójtowicz, 2013a. 
w rejestrze partii tylko 9 stanowiły ugrupowania etnoregionalne. Przy czym cztery z nich to formacje stosunkowo młode, utworzone w okresie ostatnich pięciu lat. Po dwa ugrupowania reprezentują Boszniaków i Romów, natomiast pięć Serbów. Przyczyn funkcjonowania tak małej liczby ugrupowań etnoregionalnych w Chorwacji należy przede wszystkim upatrywać w przyjętej już we wstępnej fazie transformacji ustrojowej w latach 90. zasadzie odgórnie zarezerwowanych parlamentarnych mandatów dla przedstawicieli mniejszości. Choć w czasie dekady rządów prezydenta Franja Tudźmana i jego formacji HDZ przy zabezpieczeniu tego prawa odnotowano wiele nieprawidłowości, przede wszystkim dotyczących zasad reprezentacji chorwackich Serbów (Mikucka-Wójtowicz, 2010).

Z uwagi na ograniczenia niniejszego opracowania chciałabym skupić się na funkcjonowaniu tylko dwóch grup ugrupowań etnoregionalnych, reprezentujących najliczniejsze na terenie badanych państw mniejszości, a więc partii wojwodińskich Węgrów i chorwackich Serbów.

\section{PARTIE WOJWODIŃSKICH WĘGRÓW (1990-2012)}

Mniejszość węgierską w Wojwodinie reprezentuje obecnie 6 ugrupowań, z czego 4 istnieją od lat 90., a dodatkowo 3 z nich (DZVM, DSVM i SVM) mają wspólne korzenie. Powstały one w wyniku frakcjonalizacji (a następnie rozłamów), powodowanych osobistymi animozjami między prominentnymi działaczami pierwszej partii reprezentującej tę grupę ludności, czyli założonej w styczniu 1990 roku Demokratycznej Wspólnoty Wojwodińskich Węgrów (DZVM - Demokratska zajednica vojvođanskih Mađara). Co warte podkreślenia, początkowo bardziej przypominała ona ugrupowanie regionalne niż etnoregionalne, apelowała bowiem do władz o zagwarantowanie równych praw wszystkim mniejszościom mieszkającym na terenie Wojwodiny (DZVM, 1990). Dopiero w Memorandum o samorządzie lokalnym Węgrów zamieszkujących na terenie Jugosławii z 25 kwietnia 1992 roku wyraźnie zdefiniowała jako swój nadrzędny cel reprezentowanie mniejszości węgierskiej, domagając się przyznania jej trójstopniowej autonomii10, obejmującej autonomię (1) personalną ${ }^{11},(2)$ terytorialną (zakładającą możliwość zrzeszenia się gmin, w których mniejszość węgierska stanowi większość ludności i powołania przez nią Autonomicznego Okregu Węgierskiego) oraz (3) wprowadzenia węgierskiego samorządu na terenie odizolowanych gmin (Lutovac, 1996, ss. 123-126; Mikucka-Wójtowicz, 2013a, ss. 93-94). Ponadto żądała od władz powstrzymania procesu asymilacji Węgrów (Samardžić, 1999, ss. 123-124). Z uwagi na tak określone cele, w typologii Dandoya odpowiadała ona ugrupowaniom autonomistycznym, ponieważ domagała się autonomii i przywilejów jedynie dla reprezentowanej przez siebie mniejszości.

10 Z czasem koncepcja ta, której głównym autorem był zmarły w 2010 roku Šandor Pal, ewoluowała w kierunku dwustopniowej autonomii, rozumianej jako „ograniczona suwerenność”. Miały się na nią składać: (1) autonomia personalna (czasem określana mianem kulturowo-personalnej), rozumiana jako prawo do zachowania i rozwoju przez przedstawicieli mniejszości ich tożsamości etnokulturowej oraz (2) autonomii terytorialnej, która mogła być realizowana w dwóch formach, tzn. częściowej (w gminach, w których przedstawiciele mniejszości stanowią co najmniej 5\% ludności) bądź całkowitej autonomii polityczno-administracyjne i językowo-kulturowej (na terenie gmin, w których Węgrzy stanowią bezwzględną większość ludności). Zob. Mikucka-Wójtowicz, 2013a; Pal, 1995, 2007.

11 Autonomia personalna miała być realizowana poprzez ochronę etnicznej, kulturowej, religijnej i językowej tożsamości mniejszości, obejmując poszanowanie jej tradycji oraz kultury materialnej i duchowej. W polskich opracowaniach częściej mówi się w tym kontekście o kulturowych prawach mniejszości, jednak użyte przeze mnie określenie pojawia się w nowszych pracach. (Jackson Preece, 2007; Oetere, 2010, zwł. s. 9). 
Serbskie władze ostro krytykowały postulaty partii, oskarżając ją o secesjonizm, co jest o tyle znamienne, że jednocześnie same postulowały wprowadzenie podobnych rozwiązań na terenach innych jugosłowiańskich republik, gdzie Serbowie stanowili większość (Vukomanović, 2010, s. 167). Ówczesny strateg DZVM - Šandor Pal zdecydowanie odrzucał zarzuty, twierdząc, iż wbrew propagandzie medialnej, partia nie popiera prawa do samookreślenia i secesji, ale domaga się „autonomii w sprawach osobistych”, co zakładało uznanie politycznej, zbiorowej podmiotowości mniejszości i urzeczywistnienie jej kolektywnych praw na kilku wyjątkowo ważnych płaszczyznach: szkolnictwa, kultury, urzędowego użycia języka mniejszości oraz sądownictwa (Pal, 1995). DZVM była jednak wierna obranej linii programowej i 1995 roku wznowiła kampanię na rzecz powołania Węgierskiego Okręgu Autonomicznego, który miał przybrać formę dobrowolnego stowarzyszenia gmin z przewagą ludności węgierskiej. Pomysł ów spotkał się tym razem nie tylko z krytyką władz (zarówno republikańskich, jak i federalnych), ale też opozycyjnych ugrupowań z Wojwodiny, oskarżających DZVM o szkodliwy etnocentryzm i domagających się od rządu Serbii zagwarantowania autonomii dla całej prowincji. W ich przekonaniu było to optymalne rozwiązanie służące przezwyciężeniu istniejących podziałów etnicznych, co przyczyniłoby się do społecznego i gospodarczego rozwoju regionu.

Jedność w ramach DZVM nie trwała długo. W połowie lat 90. doszło w niej do dwóch znaczących rozłamów. Najpierw w 1994 roku partię opuściła frakcja Ferenca Čubeli, który nie zgadzając się z ponownym wyborem na stanowisko przewodniczącego Andraša Agoštona, utworzył Związek Wojwodińskich Węgrów (SVM). Na czele nowej formacji początkowo stał Čubela, a po jego śmierci w 1995 roku, funkcję tę przejął Jožef Kasa. Natomiast dwa lata później, w 1996 roku, Šandor Pal oskarżył przewodniczącego Agoštona o kokietowanie prezydenta Slobodana Miloševicia i jego partii - SPS (Socjalistyczna Partia Serbii - Socjalistička partija Srbije) i domagał się od niego podjęcia przed zaplanowanymi na ten rok wyborami do parlamentu federalnego współpracy z SVM, na co Agošton nie chciał się zgodzić i pozbawił Pala dotychczasowych funkcji w partii. Jednak Pal, dzięki wsparciu swoich zwolenników, zorganizował specjalną konwencję, podczas której został wybrany na przewodniczącego. Wówczas Agošton opuścił DZVM i założył nową formację - Demokratyczną Partię Wojwodińskich Węgrów (DSVM - Demokratska stranka vojvođanskih Mađara). Prawdopodobnie wybierając nazwę tak zbieżną z nazwą macierzystej formacji, liczył na dezorientację wyborców. Jednak te nadzieje okazały się płonne. Zwycięzcą wyborów został SVM, który właściwie przejął pierwotny elektorat macierzystego ugrupowania, o czym świadczą wyniki wyborów, przedstawione w Tab. 4

Tab. 4 Wyniki uzyskiwane przez partie mniejszości węgierskiej w Serbii w wyborach parlamentarnych w latach 1990-2012

\begin{tabular}{|c|c|c|c|c|c|c|c|c|c|}
\hline & 1990 & 1992 & 1993 & 1997 & 2000 & 2003 & 2007 & 2008 & 2012 \\
\hline DZVM & $\mathbf{8}$ & $\mathbf{9}$ & $\mathbf{5}$ & & & & & & \\
\hline SVM & & & & $\mathbf{5}$ & $\begin{array}{c}\mathbf{1 0} \text { (w ramach } \\
\text { koalicji DOS) }\end{array}$ & & $\mathbf{3}$ & $\begin{array}{c}\mathbf{4} \text { (w ramach } \\
\text { Wegierskiej Koalicji - } \\
\text { Ištvan Pastor). } \\
\text { W jej sktad } \\
\text { wchodzity SVM, DZVM } \\
\text { oraz DSVM. }\end{array}$ & $\mathbf{5}$ \\
\hline
\end{tabular}

DZVM (Demokratska zajednica vojvođanskih Mađara) - Demokratyczna Wspólnota Wojwodińskich Węgrów SVM (Savez vojvođanskih Mađara) - Związek Wojwodińskich Węgrów

Źr ó d to: Opracowanie własne na podstawie wyników wyborów publikowanych przez Republikańską Komisję Wyborczą (Republička Izborna Komisija). 
Analizując ofertę programową trzech wskazanych partii węgierskich, należy przede wszystkim zauważyć, iż rozłamy w DZVM, oraz profil ugrupowań powstałych w ich następstwie stoją w sprzeczności z niegdyś bardzo rozpowszechnioną hipotezą, że zwiększenie rywalizacji wśród partii etnicznych właściwie nieuchronnie prowadzi do efektu przelicytowania etnicznego i radykalizacji postaw elektoratów. SVM początkowo przejął naczelne zasady programowe macierzystej formacji wraz z koncepcją zagwarantowania Węgrom trójstopniowej autonomii. Choć za główny cel partia postawiła sobie urzeczywistnienie prawa członków mniejszości węgierskiej do zachowania i rozwoju tożsamości i języka oraz umożliwienia węgierskim dzieciom edukacji w języku macierzystym, nie porzuciła krytykowanego przez władzę i opozycję postulatu powołania Węgierskiego Okręgu Autonomicznego oraz węgierskiego samorządu o szerokich kompetencjach (o ile pierwszemu z pomysłów pozostała w miarę wierna, drugi porzuciła już w następnym roku), czemu dała wyraz w przyjętym w 1996 roku dokumencie - Projekt porozumienia w sprawie podstaw samoorganizacji wojwodińskich Wegrów (Samardžić, 1999, s. 135). W początkowej fazie działalności formacja ta wyraźnie szukała swego profilu programowego, oscylując między typami określanymi przez Dandoya mianem partii autonomistycznych i protekcjonistycznych partycypujących. W późniejszym okresie - i to zarówno jeszcze w latach 90., ale także po demokratycznym przełomie, a więc odejściu ekipy prezydenta Miloševicia i przejęciu władzy przez opozycję demokratyczną- SVM zdarzało się zmieniać dyskurs (zwykle, choć nie zawsze, poprzez radykalizację apeli - etniczne przelicytowanie). Do zmian tych dochodziło zwłaszcza przed wyborami lub w okresie eskalacji kryzysu w Kosowie (np. w 1999 i 2008 roku). Dobrym przykładem sięgnięcia po krańcowo odmienne strategie były sytuacje z 2005 i 2008 roku.

Przed wyborami parlamentarnymi w 2008 roku (przeprowadzonymi niespetna trzy miesiące po jednostronnym ogłoszeniu niepodległości przez Kosowo) nowy lider SVM Ištvan Pastor stanął na czele wyborczej koalicji ugrupowań reprezentujących mniejszość węgierską (zrzeszającej SVM, DZVM i DSVM). Koalicjanci przyjęli wówczas specjalny dokument (Wspólna koncepcja autonomii partii wojwodińskich Wegrów), w którym - kolejny już raz - postulowano zagwarantowanie przedstawicielom mniejszości węgierskiej autonomii personalnej (kulturowo-personalnej) i politycznej, która miała być zrealizowana dzięki powołaniu specjalnego etnicznego samorządu terytorialnego i zwiększeniu uprawnień tzw. rad mniejszości ${ }^{12}$ oraz autonomii Wojwodiny. Podczas kampanii Pastor apelował też do rządu w Budapeszcie o przyznanie wojwodińskim Węgrom podwójnego obywatelstwa, a opozycyjny wówczas FIDESZ obiecywał przeprowadzenie referendum w tej sprawie Choć taki postulat już raz upadł w referendum w 2004 roku (po akcesji Węgier do UE). Radykalizacja postulatów partii węgierskich zyskała aprobatę wyborców (zdobyły one 70 tys. głosów, co dało koalicji 4 mandaty, wszystkie przypadły SVM), jednak była ostro krytykowana przez przedstawicieli mainstreamowych partii serbskich, nawet nastawionej promniejszościowo DS ówczesnego prezydenta Borisa Tadicia.

\section{$\cdots \cdots \cdot$}

12 Pierwszy raz koncepcja powołania specjalnych rad reprezentujących poszczególne mniejszości narodowe mieszkające na terenie Wojwodiny (a później także całej Serbii), jako ciała opiniodawczego i doradczego, pojawiła się programie SVM z 1998 roku, a Jožef Kasa został nawet zaproszony przez S. Miloševicia (piastującego wówczas stanowisko prezydenta Jugosławii) do rozmów w tej sprawie. Oficjalnie na terenie Wojwodiny powołano wówczas jedną, wspólną dla wszystkich mniejszości, Radę ds. Urzeczywistnienia Praw Mniejszości Narodowych i Grup Etnicznych. Natomiast powołanie rad na takiej zasadzie i o takich kompetencjach, jak pierwotnie zakładał SVM, zostało przewidziane dopiero w uchwalonej w 2002 roku Ustawie o prawach mniejszości, choć zgodnie z zawartymi w niej przepisami, rady zostały powołane dopiero osiem lat później. 
Jest to o tyle ciekawe, iż kiedy w 2005 roku liderzy DZVM (Š. Pal), DSVM (A. Agošton) i GSVM (Obywatelskie Forum Wojwodińskich Węgrów - Građanski forum vojvođanskih Mađara, Laslo Rac Sabo ${ }^{13}$ ), zwrócili się do prowadzącego międzynarodowe rozmowy o przyszłości Kosowa Martti Ahtisaariego, z prośbą o równoległe prowadzenie rozmów w sprawie zagwarantowania autonomii wojwodińskim Węgrom, pomysł ten został ostro skrytykowany przez ówczesnego lidera SVM - Jožefa Kasę. Kasa uważat, iż jest to wewnętrzna sprawa Serbii, która nie powinna zostać umiędzynarodowiana. Choć znów, jeszcze w 1999 roku, również w czasie eskalacji kryzysu w Kosowie, prowadził on rozmowy z premierem Wiktorem Orbanem, który obiecał wspierać na forum międzynarodowym koncepcję autonomii Wojwodiny i wojwodińskich wspólnot narodowych, tym razem rozumianą jako zagwarantowanie autonomii całego regionu Wojwodiny (mimo iż wcześniej Kasa wielokrotnie podkreślał, iż dla Węgrów jest to kwestia drugorzędna), w obrębie której miała też być zagwarantowana specjalna autonomia terytorialna i personalna dla członków mniejszości węgierskiej.

Innym przykładem zmiany strategii SVM była wspomniana sytuacja z 2009 roku, kiedy radykalizacja postulatów partii nie dotyczyła mniejszości węgierskiej lecz przyszłości całego regionu. SVM odwołał się wówczas do strategii przelicytowania nieetnicznego, w celu odebrania zwolenników regionalnemu LSV, a po części także rządzącej wówczas DS. Oba ugrupowania starały się bowiem przedstawić jako rzeczniczki odzyskania przez Wojwodinę autonomii, jaką prowincja miała przed 1989 rokiem. Zresztą w ostatnich latach Ištvan Pastor kilkakrotnie starał się wyjść poza etnicznie zaszufladkowany elektorat, nazywając SVM formacją regionalną.

Z kolei profil obrany przez DSVM sugeruje, iż można tę formację przyporządkować typowi nazwanemu przez Dandoya mianem partii protekcjonistycznej partycypującej, co kolejny raz podaje w wątpliwość tezę o nieuchronności przelicytowania etnicznego. Strategię DSVM można raczej postrzegać jako obniżenie, w stosunku do macierzystej formacji, pułapu żądań, a więc zmniejszenia stawki etnicznej. DSVM postuluje bowiem zagwarantowania mniejszości węgierskiej autonomii kulturowej (zamiast trójstopniowej autonomii), zapewnienia jej przedstawicielom proporcjonalnej reprezentacji w parlamencie, dzięki wprowadzeniu instytucji odgórnie zarezerwowanych miejsc. Jedynym bardziej radykalnym postulatem partii jest wprowadzenie podwójnego obywatelstwa.

Na uwage zasługuje też najmłodsze spośród ugrupowań pretendujących do reprezentowania wojwodińskich Węgrów, a mianowicie utworzony w 2009 roku Ruch Węgierskiej Nadziei (Pokret mađraske nade - PMN), pozostający pod silnym wpływem węgierskiej formacji Jobbik. Domaga się on zapewnienia mniejszości węgierskiej takiego samego zakresu autonomii terytorialnej, jaka została zagwarantowana Serbom z Kosowa na mocy tzw. porozumienia brukselskiego z kwietnia 2013 roku. Zaś jego apele cechuje wyraźna ksenofobia, wymierzona przede wszystkim w mieszkającą na terenie Wojwodiny mniejszość romską. W 2012 roku lider PMN - Balint Pastor, zdecydował nawet o utworzeniu - wzorowanych na bojówkach Jobbiku - tzw. patroli obywatelskich, które miały przeciwdziałać fali kradzieży na terenie prowincji. Działania tej formacji doskonale się wpisują w strategie przelicytowania etnicznego, jednak jej wyborczy wynik pokazał, iż taka radykalizacja nie ma poparcia wyborców .

\footnotetext{
13 GSVM powstał w 1995 roku, iż mimo że określał się mianem czołowego reprezentanta wojwodińskich Węgrów, w rzeczywistości pozostał formacją marginalną.
} 
W Chorwacji od początku lat 90. obowiązuje zasada odgórnie zarezerwowanych miejsc dla przedstawicieli mniejszości, przy czym liczba przysługujących im mandatów zmieniała się na mocy kolejnych ordynacji, a zmiany te w największym stopniu dotykały (i dyskryminowały) ludność serbską. Choć właśnie zabezpieczenie jej praw stanowiło najważniejszy wymóg uznania suwerenności Chorwacji stawiany przez Wspólnoty Europejskie ${ }^{14}$. Początkowo, pod naciskiem WE, mniejszość serbska na mocy ordynacji z 1992 roku uzyskała prawo reprezentacji proporcjonalnej do jej udziału w strukturze ludności, czyli jej przedstawicielom zagwarantowano 13 mandatów w niższej izbie parlamentu. Zastrzeżono przy tym, iż jeśli nie uda się im ich zdobyć w wyniku rywalizacji wyborczej, Sąd Konstytucyjny ma prawo do ich obsadzenia przedstawicielami tejże mniejszości startującymi z list innych ugrupowań biorących udział wyborach ${ }^{15}$. Następnie, na podstawie ordynacji z 1995 roku liczba mandatów przysługujących chorwackim Serbom zmniejszyła się do trzech, zaś w 1999 zaledwie do jednego. Prawo do wybierania trzech deputowanych zostało im przywrócone po tzw. przełomie demokratycznym, czyli przejęciu władzy w Chorwacji w 2000 roku przez szeroką koalicję ugrupowań prodemokratycznych (Mikucka-Wójtowicz, 2010).

Obecnie w Chorwacji funkcjonuje pięć ugrupowań reprezentujących mniejszość serbską, z czego trzy: SNS (Srpska narodna stranka - Serbska Partia Ludowa), SDSS (Samostalna demokratska srpska stranka - Niezależna Demokratyczna Partia Serbska) i PPS (Partija podunavskih Srba - Partia Naddunajskich Serbów) powstały jeszcze w latach 90. XX wieku. Zaś dwa kolejne: DPS (Demokratska partija Srba - Demokratyczna Partia Serbów) i NSS (Nova srpska stranka - Nowa Serbska Partia) mają dość krótki staż, bo zostały zarejestrowane dopiero w 2009 roku. Natomiast w pierwszej połowie lat 90. znaczącą rolę dla politycznej i etnicznej mobilizacji chorwackich Serbów odegrała Serbska Partia Demokratyczna (Srpska demokratska stranka - SDS). Trzeba wyraźnie zaznaczyć, iż sytuacja ugrupowań reprezentujących chorwackich Serbów była i jest bardziej skomplikowana niż w przypadku partii wojwodińskich Węrów. Początki funkcjonowania części z nich przypadły na czas trwania otwartego konfliktu etnicznego, jaki toczył się w pierwszej połowie lat 90. między Serbami i Chorwatami, na terenach Chorwacji zamieszkanych przez mniejszość serbską, przede wszystkim w Krajinie (gdzie Serbowie proklamowali samozwańczą Republikę Serbskiej Krajiny) oraz w Slawonii. Także obecnie partie serbskie działają w regionach postkonfliktowych, w których wciąż sporadycznie dochodzi do napięć na tle etnicznym. Doskonałym przykładem tego były protesty, które wybuchły na początku września 2013 roku w Vukowarze, gdy władze próbowały wprowadzić dwujęzyczne tablice na budynkach administracji publicznej.

\section{......}

14 Pod naciskiem WE 4 grudnia 1991 r. Sabor uchwalił Ustawę konstytucyjną o prawach człowieka $i$ wolnościach wspólnot oraz mniejszości etnicznych i narodowych w Republice Chorwacji, między innymi gwarantującą mniejszościom, których udział w strukturze ludności wynosi ponad $8 \%$ ogółu obywateli (a więc de facto mniejszości serbskiej stanowiącej 12,2 \% obywateli Chorwacji), prawo do proporcjonalnej reprezentacji w parlamencie. Jak się później okazało, z tego prawa mogli oni skorzystać jedynie w wyborach parlamentarnych w 1992 roku. Później Sabor zawiesił ów przepis, z uwagi na ich znaczący ubytek. Zob. MikuckaWójtowicz, 2010.

15 Na listach innych ugrupowań było łącznie 10 kandydatów narodowości serbskiej [8 na liście Socjaldemokratycznej Partii Chorwacji (SDP) oraz 2 na liście Chorwackiej Partii Ludowej (HNS)]. Dodatkowo, w celu uzyskania pożądanej wielkości reprezentacji, Sąd Konstytucyjny zdecydował o przydzieleniu 3 brakujących mandatów Serbskiej Partii Narodowej (Srpska narodna stranka - SNS), uznając, iż w tym przypadku przekroczenie przez nią progu wyborczego nie było konieczne. Zaraz po wyborach, władze zmagającej się z piętnem komunistycznej przeszłości SDP, która nie chciała dodatkowo uchodzić za formację proserbską, doprowadziły do wystąpienia z jej szeregów 5 spośród 8 mianowanych z jej list parlamentarzystów narodowości serbskiej, którzy następnie piastowali mandaty jako deputowani niezależni. 
Pierwszą partią aspirującą do reprezentowania zamieszkałych w Chorwacji Serbów była utworzona w lutym 1990 roku - czyli przed pierwszymi rywalizacyjnymi wyborami - Serbska Partia Demokratyczna (SDS), na której czele stanął Jovan Rašković. Mimo wielu zarzutów o nacjonalizm pod jego adresem, był on, jak się później okazało, najbardziej umiarkowanym politykiem tej formacji (Judah, 2009, s. 168). Choć sam przyznawat, że nie był bez winny dla eskalacji konfliktu etnicznego na terenach Chorwacji zamieszkanych przez Serbów, zwłaszcza w Krajnie. Rašković stwierdził wprost, iż on i SDS, przyczynili się do wzrostu napięcia emocjonalnego wśród członków mniejszości serbskiej, odpalając lont serbskiego nacjonalizmu, nie tylko w Chorwacji, ale też w Bośni, gdzie utworzono siostrzaną formację SDS (Rašković, Vreme, 27.01.1992, s. 56, za: Knežević, 2011).

Początkowo, przynajmniej na gruncie programowym, SDS zajmowała umiarkowaną pozycję. Jej głównym postulatem było zagwarantowanie mniejszości serbskiej autonomii kulturalnej, a w jego realizacji miała pomóc demokratyzacja państwa (między innymi dzięki wprowadzeniu instytucji uczciwych i wolnych wyborów) oraz utrzymanie jego federalnej struktury (SDS, 1990b). Przy czym, choć Rašković twierdził, że żądanie autonomii politycznej byłoby błędem, równocześnie straszył chorwackie władze, iż „Na każdy krok Tudźmana zmierzający do secesji z Jugosławii, Serbowie będą odpowiadali krokiem w kierunku wyjścia z Chorwacji" (Goldstein, 2008, s. 663). Łagodził jednak te groźby stwierdzeniem, iż ewentualna decyzja w tej sprawie powinna zostać podjęta przez Serbów w drodze referendum (Caspersen, 2003, ss. 5-6) ${ }^{16}$. Ponadto $w$ dokumentach programowych SDS tłumaczyła także, iż sprzeciwia się postępującej etnicyzacji polityki i mimo podkreślenia w swej nazwie proweniencji etnicznej, pozostaje ona przede wszystkim ugrupowaniem propagującym uniwersalne demokratyczne wartości (SDS, 1990a, s. 340).

Zresztą rozziew między przestawioną platformą programową a retoryką używaną przez działaczy partyjnych podczas wystąpień publicznych (wyraźnie widoczny już w początkowym okresie działania partii), prawdopodobnie był jedną z przyczyn jej słabego wyniku w wyborach parlamentarnych w 1990 roku. SDS zdobyła w nich jedynie 5 spośród 37 mandatów, które przypadły deputowanym podkreślającym serbskie pochodzenie ${ }^{17}$. Wraz z eskalacją konfliktu etnicznego w Krajnie i Slawonii, za co odpowiedzialność ponosity zarówno rząd w Belgradzie, jak i Zagrzebiu (a nie bez winy były też prorządowe media w obu krajach, podsycające u obu stron konfliktu poczucie zagrożenia), większość "serbskich parlamentarzystów" opuściła Sabor. Do końca krótkiej, bo zakończonej już w 1992 roku, kadencji dotrwało jedynie ośmiu deputowanych. Zaś sama SDS - w następstwie czynnego zaangażowania się w konflikt etniczny, który wybuchł na terenie Krajiny w 1991 roku - została zdelegalizowana przez Sąd Konstytucyjny, który uznał, iż jej działalność grozi naruszeniem integralności kraju i obowiązującego porządku prawnego. (Zakošek, 2002, s. 33).

6 Badacze często dziwia się, skąd w poglądach Raškovicia tyle ambiwalencji. Trzeba jednak pamiętać, iż choć na początku lat 90. Rašković rzeczywiście uchodził za największego w SDS zwolennika autonomii kulturalnej, był on również współautorem tzw. Deklaracji kninskiej, napisanej w 1989 roku wraz ze swoim przyjacielem Dobricą Ćosiciem (pisarzem i późniejszym prezydentem tzw. III Jugosławii, uchodzącym za ojca serbskiego nacjonalizmu w latach 90.). Jej głównym przesłaniem był apel do ówczesnych jugosłowiańskich władz o wydzielenie w ramach istniejącego państwa federalnego nowej jednostki ze stolicą w Kninie, która miała reprezentować Serbów z Krajiny (Artman, 2001, s. 68).

17 W pierwszych wolnych wyborach chorwaccy Serbowie najczęściej głosowali na postkomunistyczną SKH -SDP (Związek Komunistów Chorwacji - Partia Demokratycznych Przemian), której głównym postulatem była ochrona i utrzymanie państwa federalnego w dotychczasowym kształcie, co było zbieżne z celami mniejszości serbskiej. Jednak po wyborach SDP dość szybko porzuciła ów postulat, co doprowadziło utraty jej wiarygodności wśród Serbów. (Caspersen, 2003, s. 5; Goldstein, 2008, s. 657). 
Po wyborach z 1990 roku Rašković znalazł się pod silną presją, i to zarówno wewnętrzną, jak i zewnętrzną. Mimo niesprzyjających okoliczności podjął wówczas rozmowy z prezydentem Tuđmanem (będącym zarazem liderem rządzącej Chorwackiej Wspólnoty Demokratycznej) o zagwarantowaniu Serbom autonomii kulturalnej, co nie podobato się ani radykalnemu skrzydłu partii - coraz silniej domagającemu się autonomii terytorialnej, a później secesji - reprezentowanemu przede wszystkim przez jego zastępcę Milana Babicia oraz późniejszego prezydenta samozwańczej Republiki Serbskiej Krajiny - Milana Marticia, które oskarżało Raškovicia o zdradę, ani władzom w Belgradzie, straszącym chorwackich Serbów, że zwycięstwo HDZ doprowadzi do eksplozji nacjonalizmu w Chorwacji, a Serbowie utracą posiadane dotychczas prawa. W rzeczywistości polityka Tuđmana i rządzącej HDZ wobec Serbów cechowała się dużą ambiwalencją. Z jednej strony, pod presją społeczności międzynarodowej, Tuđman deklarował poszanowanie praw mniejszości. Z drugiej, na mocy uchwalonej 25 lipca 1990 nowelizacji dotychczasowej, socjalistycznej konstytucji Serbowie, cieszący się do tej pory statusem narodu konstytucyjnego, zostali zdegradowani do pozycji mniejszości narodowej. Zmiany te, mimo ostrego sprzeciwu ze strony mniejszości serbskiej, zostały następnie potwierdzone w uchwalonej 22 grudnia 1990 roku nowej ustawie zasadniczej ${ }^{18}$. Ponadto dość liczne były przypadki zwolnień przedstawicieli mniejszości serbskiej w administracji państwowej (a przede wszystkim policji), co było tłumaczone przez władze chorwackie dążeniem do tego, by struktura etniczna urzędów odzwierciedlała strukturę ludności państwa (Caspersen, 2003, s. 4; Goldstein, 2008, ss. 660-661). Działania te bezsprzecznie przyczyniły się do radykalizacji poglądów części działaczy SDS na czele z Milanem Babiciem (coraz wyraźniej wspieranym przez ówczesnego prezydenta Serbii Slobodana Miloševicia) oraz sięgnięcia przez nich podczas wewnątrzpartyjnej rywalizacji o fotel przewodniczącego partii w styczniu 1991 roku po strategię przelicytowania etnicznego. Wprawdzie to pierwsze podejście do odsunięcia od władzy Raškovicia skończyło się fiaskiem, i to mimo otwartego wsparcia Babicia przez władze w Belgradzie. Stosunek głosów członków Rady Naczelnej SDS wyniósł 38:42 na korzyść Raškovicia (Caspersen, 2003, s. 7). Jednak dwa miesiące później, po tzw. incydencie nad Jeziorami Plitwickimi, do którego doszło w Wielkanoc 1991 roku (w wyniku starć między policją chorwacką i rebeliantami serbskimi, każda ze stron poniosła jedną ofiarę śmiertelną), frakcja radykalna wyraźnie urosła w siłę i udało jej się zmarginalizować znaczenie Raškovicia.

W 1991 roku, gdy SDS coraz bardziej była zaabsorbowana wewnętrznymi konfliktami, pojawity się dwie nowe organizacje, aspirujące do reprezentowania mniejszości serbskiej i postulujące pokojowe rozwiązanie konfliktu. Były to Serbskie Forum Demokratyczne

18 Odpowiedzią mniejszości serbskiej z Kninu na lipcową nowelizację konstytucji było powołanie Serbskiej Rady Narodowej (Srpsko nacionalno veće - SNS), która na stanowisko swego przewodniczącego wybrała Milana Babicia (wiceprzewodniczącego SDS i burmistrza Kninu). Jeszcze tego samego dnia SNS ogłosita Deklarację o suwerenności i autonomii Serbów w Chorwacji oraz rozpisała na sierpień 1990 roku referendum w sprawie autonomii dla chorwackich Serbów (za którego przeprowadzeniem gorąco lobbował wspierający buntowników serbski prezydent Slobodan Milošević). Jego wyniki nie zostały jednak uznane przez chorwackie władze. Natomiast, wiedząc, iż krytykowane rozwiązania zostaną utrzymane w nowej konstytucji, dzień przed jej ogłoszeniem, 21 grudnia 1990 roku, Serbowie z Krajiny proklamowali utworzenie Serbskiego Okręgu Autonomicznego Krajiny (SAO Krajine) oraz ogłosili jego statut, na mocy którego między innymi 5 spośród 11 gmin z przewagą serbskiej ludności w tym regionie, przestało odprowadzać podatki do państwowej kasy. 1 kwietnia 1991 roku, w następstwie kolejnego referendum przeprowadzonego w marcu 1991 r., władze SAO Krajiny zapowiedziały secesję regionu i jego przyłączenie do Serbii. Zaś 19 grudnia 1991 r. jednostronnie proklamowały niepodległość Republiki Serbskiej Krajiny (RSK). Samozwańcze państwo chorwackich Serbów nie zostało uznane przez społeczność międzynarodową, jednak oficjalnie istniało do sierpnia 1995 roku, gdy chorwackiemu wojsku udało się odzyskać sporne tereny w wyniku akcji Burza (Oluja). (Goldstein, 2008, ss. 665-678). 
(Srpski demokratski forum - SDF), zrzeszające serbskich intelektualistów ${ }^{19}$, którego liderem został Milorad Pupovac, a w jego tworzeniu brał udział m.in. Jovan Rašković oraz Serbska Partia Ludowa (Srpska narodna stranka - SNS) założona przez Milana Đukicia, wyrzuconego z SDS przez Milana Babicia po tzw. incydencie nad Jez. Plitwickimi, za sprzeciwianie się pomystowi ogłoszenia secesji Krajiny. Co warte podkreślenia, wbrew popularnym hipotezom, iż wewnątrzetniczna rywalizacja prowadzi do radykalizacji graczy, zachęcając ich do sięgania po strategię przelicytowania etnicznego (czemu zresztą dodatkowo powinien iść w sukurs fakt, iż zostały one założone w momencie trwania konfliktu etnicznego), oba ugrupowania prezentowały umiarkowane stanowisko i postulowały szukanie pokojowych możliwości rozwiązania konfliktu. SDF popierało istnienie suwerennego państwa chorwackiego w obecnych granicach, zaś możliwość rozwiązania konfliktu widziało w zagwarantowaniu mniejszości serbskiej szerokiej autonomii (Caspersen, 2003, s. 8). Także SNS uznawała suwerenność Chorwacji i innych republik postjugosłowiańskich, w ich obecnych granicach, zaznaczając, iż mogą się one zmienić jedynie na "podstawie historycznej umowy wszystkich zainteresowanych stron" oraz postulowała przyznanie mniejszości serbskiej „autonomii kulturalnej, w zgodzie z europejskimi kryteriami i modelami" (SNS, 1997, s. 263). Ponadto działacze SNS otwarcie krytykowali macierzystą formację - SDS za „działanie niedemokratycznymi, wręcz niecywilizowanymi metodami" (SNS, 1997, s. 261) oraz odmawiali legitymizacji powołanym przez jej radykalną frakcję instytucjom Serbskiej Republiki Krajiny, kwestionując ich prawo do reprezentowania mniejszości serbskiej na tym obszarze (Taleski, 2011, s. 10).

De facto więc obie formacje, postulując zagwarantowanie Serbom autonomii kulturalnej, przyjęły strategię nazywaną przez Coakleya i Zuber mianem zmniejszenia stawki etnicznej. Później w programie SNS coraz wyraźniejszy był postulat decentralizacji państwa i przyznania większej władzy regionom, co pozwala zaliczać tę formację do ugrupowań nazwanych przez Dandoya federalistycznymi. W przypadku tych formacji wyraźna była zbieżność ich umiarkowanej platformy programowej i retoryki stosowanej podczas wystąpień publicznych. Jest to o tyle istotne, iż pierwsze lata ich działalności przypadały na trudny dla mniejszości serbskiej w Chorwacji okres eskalacji konfliktu etnicznego na zamieszkanych przez nią terenach. Po wyborach w 1992 roku SNS miała trzech²0, a w 1995 roku dwóch deputowanych w Saborze. Ponadto w latach 1992-1995 jej przewodniczący Milan Đukić pełnił funkcję wicemarszałka Saboru, przez co zresztą tę partię często określano pejoratywnym mianem: „Partii Serbów Tuđmana”.

W drugiej połowie lat 90. drogi Tuđmana i Đukicia zaczęły się wyraźnie rozchodzić, a stanowisko SNS uległo radykalizacji, na co nie bez wpływu była nieustająca nagonka na ludność serbską oraz przejawy jej dyskryminacji. Dobrym przykładem jest chociażby ordynacja wyborcza przyjęta w 1999 roku, na mocy której mniejszości serbskiej przysługiwał zaledwie jeden mandat. Według Dane Taleskiego, ówczesna radykalizacja postulatów SNS - domagającej się szerokiej autonomii terytorialnej z rządem, legislatywą i serbską administracją odpowiadającą za funkcjonowanie lokalnej policji, służby zdrowia, edukacji, handlu i rozwoju - przesądziła o sukcesie wyborczym tej formacji w wyborach w 2000 roku (Taleski, 2011, s. 11), którego jednak nie udało jej się powtórzyć w kolejnych cyklach wyborczych.

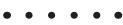

19 Początkowo SDF wyrażało aspiracje polityczne, jednak ostatecznie przekształciło się w organizację pozarządową.

20 O sposobie zdobycia przez nią mandatów w tych wyborach pisałam w przyp. 15. 
Ostatnim ugrupowaniem wartym krótkiej refleksji jest utworzona w październiku 1995 roku Niezależna Demokratyczna Partia Serbska (Samostalna demokratska srpska stranka - SDSS), która od 2003 roku nieprzerwanie zdobywa wszystkie trzy mandaty zagwarantowane mniejszości serbskiej. W latach 2007-2011 SDSS wchodziła też w skład dwóch kolejnych rządów tworzonych przez HDZ. Partia ta reprezentuje umiarkowane poglądy w kwestiach etnicznych. Jej główne postulaty dotyczą zagwarantowania Serbom autonomii kulturalnej oraz urzeczywistnienia ich prawa do proporcjonalnej reprezentacji w Saborze i organach przedstawicielskich jednostek samorządu lokalnego oraz władzy sądowniczej (co zresztą gwarantuje mniejszościom ustawa konstytucyjna z 2002 roku²1), jak również troski o serbskich uchodźców. W jej programie pojawia się też postulat decentralizacji państwa na zasadach „zrównoważonego regionalizmu”, a więc scedowania części uprawnień władz centralnych na władze jednostek niższego szczebla (regionalnych bądź lokalnych) (SDSS, 2005). Umiarkowane stanowisko SDSS jest o tyle ciekawe, że partia ta powstała w wyniku połączenia „progresywnych serbskich sił i opcji politycznych działających we wschodniej Slawonii, Baranii i zachodnim Sremie", obejmujących poza różnymi grupami politycznymi także bojówki paramilitarne z Niezależną Partią Serbską (Samostalna srpska stranka - SSS), której liderem był Milorad Pupovac, zresztą do dziś piastujący stanowisko wiceprzewodniczącego w nowej formacji (HIDRA, 2005, s. 125; Taleski, 2011, s. 12).

\section{WNIOSKI}

Przeprowadzona analiza funkcjonowania partii etnoregionalnych w Serbii i Chorwacji w odniesieniu do przywołanych w artykule teoretycznych założeń dotyczących działalności ERP, pozwala na wypunktowanie kilku wniosków. Po pierwsze, nie jest rzadkim zjawiskiem, iż partie tego typu zmieniają zarówno swoje postulaty, jak i strategie. Niektóre, jak pokazywał przykład Partii Akcji Demokratycznej z Sandżaku (SDA), robią - bądź robiły - to nawet dość często. Zmiany te, mające na celu maksymalizację zysków wyborczych, choć z pewnością poprzedzone namysłem, nie zawsze okazywały się skuteczne. Dobrym przykładem było zaostrzenie retoryki przez Serbską Partię Ludową (SNS), które choć przyniosto jej sukces w wyborach w 2000 roku, gdy szykany i przejawy dyskryminacji mniejszości były silne, okazało się chybione w kolejnych cyklach wyborczych, gdy dyskurs i działania chorwackich rządów w tym zakresie stały się bardziej umiarkowane. Oczywiście zmiany nie zawsze muszą oznaczać radykalizację stanowiska w kwestiach etnicznych. Mogą też prowadzić do zmniejszenia stawki etnicznej rywalizacji, w celu poszerzenia elektoratu o wyborców bardziej umiarkowanych lub z innych grup etnicznych. Jednak, jak pokazuje przypadek Związku Wojwodińskich Węgrów (SVM), możliwe jest, iż partie te zaczną wówczas „przelicytowywać się” z ugrupowaniami nieetnicznymi.

Po drugie, istotny wpływ na zmiany strategii partii etnoregionalnych ma zarówno polityka w stosunku do mniejszości państwa, na terenie którego dana mniejszość zamieszkuje, jak i jej państwa macierzystego. Najgorszą sytuacją jest, gdy w obu dominuje silnie narodowy czy wręcz nacjonalistyczny dyskurs, co było widać na przykładzie pełnych sprzeczności działań i przekazów Serbskiej Partii Demokratycznej (SDS), w latach 1990-1991.

Po trzecie, wewnątrzetniczna rywalizacja oczywiście może prowadzić do radykalizacji części partii czy elektoratu danej grupy etnicznej, jednak z pewnością nie jest nieuchron-

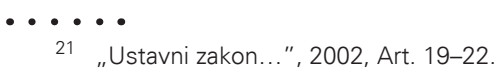


na, nawet w obliczu konfliktu. Przypadek partii serbskich założonych w Chorwacji w - i po - 1991 roku, a więc właśnie okresie eskalacji konfliktu etnicznego, pokazuje, iż wbrew wcześniejszym hipotezom, nowe ugrupowania niekoniecznie muszą sięgać po strategię przelicytowania etnicznego, a nawet odwrotnie - często decydują się na zmniejszenie stawki etnicznej. Także partie powstałe w wyniku rozłamu w Demokratycznej Wspólnocie Wojwodińskich Węgrów (DZVM) - pierwszym reprezentującym ich ugrupowaniu - generalnie zdają się potwierdzać tę odwrotną od wcześniejszych założeń tendencję.

\section{BIBLIOGRAFIA}

Artman, F. (2001). Milošević dijagonala laufera (Milosevic la diagonale du fou). Beograd: Dan Graf.

Barber, B. (1997). Dżihad kontra McŚwiat. Warszawa: Muza.

Bartolini, S. (2000). Collusion, competition and democracy: Part II. Journal of Theoretical Politics, 12(1), 33-65. doi: 10.1177/0951692800012001002

Beyme, K. von (2002). Transformacija političkih stranaka. Zagreb: Fakultet političkih znanosti.

Bochsler, D. (2010). Regional party systems in Serbia. W V. Stojarova \& P. Emerson (Red.), Party politics in the Western Balkans (ss. 131-150). London, New York: Routledge.

Bochsler, D., \& Szöcsik, E. (2013). The forbidden fruit of federalism: Evidence from Romania and Slovakia. West European Politics, 36(2), 426-446. doi: 10.1080/01402382.2 013.749667

Brancati, D. (2008). The origins and strengths of regional parties. British Journal of Political Science, 38(01), 135-159. doi: 10.1017/S0007123408000070

Broj Mađara u Srbiji se smanjio za 40000. (2012, grudzień 3). Vesti Online. Pobrano 5 kwietnia 2014, z http://www.vesti-online.com/Vesti/Srbija/274390/Broj-Madara-u-Srbiji-se-smanjio-za-40000

Bugajski, J. (1994). Ethnic politics in Eastern Europe: A guide to nationality policies, organizations and parties. New York: M. E. Sharpe.

Čanak (LSV): SVM ne podržava Cvetkovićevu vladu. (2009, grudzień, 22). Pobrano 5 kwietnia 2014, z http://www.politika.rs/rubrike/dogadjaji-dana/CHanak-LSV-SVM-nepodrzava-Cvetkovicevu-vladu.It.html

Caspersen, N. (2003). The thorny issue of ethnic autonomy in Croatia: Serb leaders and proposal for autonomy. Journal on Ethnopolitics and Minority Issues in Europe, 3, 1-26.

Castells, M. (2008). Siła tożsamości. Warszawa: PWN.

Chandra, K. (2005). Ethnic parties and democratic stability. Perspectives on Politics, 3(02). doi: $10.1017 /$ S1537592705050188

Chandra, K. (2011). What is an ethnic party? Party Politics, 17(2), 151-169. doi: $10.1177 / 1354068810391153$

Coakley, J. (2008). Ethnic competition and the logic of party system transformation. European Journal of Political Research, 47(6), 766-793. doi: 10.1111/j.14756765.2008.00824.x

Dandoy, R. (2008). Ethno-regionalist parties in Europe: a typology. Paper presented at ECPR Graduate Conference, Barcelona, 25-27 July 2008. Pobrano 4 kwietnia 2014, z http:// dev.ulb.ac.be/sciencespo/en/membres-publications_dandoy-regis_conferences.html 
Dandoy, R. (2009). An understudied category of ethno-regionalist parties in Europe: the case of the rattachist parties. Paper presented at IPSA World Congress of Political Science, Santiago, 12-16 July 2009. Pobrano 5 kwietnia 2014, z http://dev.ulb.ac.be/ sciencespo/dossiers_membres/dandoy-regis/fichiers/dandoy-regis-publication71.pdf

Dandoy, R. (2010). Ethno-regionalist parties in Europe: a typology. Perspectives on Federalism, 2(2), 195-220.

De Winter, L. (1998). Conclusion. A comparative analysis of the electoral, office and policy success of ethnoregionalist parties. W L. de Winter \& H. Türsan (Red.), Regionalist parties in Western Europe (ss. 204-247). London, New York: Routledge.

De Winter, L., \& Gomez-Reino Cachafeiro, M. (2002). European integration and ethnoregionalist parties. Party Politics, 8(4), 483-503. doi: 10.1177/1354068802008004007

Demokratska zajednica vojvođanskih Mađara [DZVM] (1990). Program 1989. W V. Pavlović i in. (Red.), Nove stranke Srbije. Dokumenti novih političkih stranaka i grupa u Srbiji (ss. 31-37). Beograd: Institut za političke studije.

Faron, J. D. (2003). Ethnic structure and cultural diversity around the world: A cross-national data set on ethnic groups. Pobrano 4 kwietnia 2014, z http://www.stanford.edu/ group/ethnic/workingpapers/egroups.pdf

Goldstein, I. (2008). Hrvatska 1918-2008. Zagreb: EPH \& Novi Liber.

Gomez-Reino Cachafeiro, M. (2008). A niche or an expanding universe for ethnoregionalist parties in Europe? Party demands in contemporary European politics. Paper prepared for the conference: Nationalism, Regionalism and Religion, London, 17-18 October 2008. Pobrano 4 kwietnia 2014, z https://nanovic.nd.edu/assets/8832/gomez_reino_paper_2008.pdf

Gunther, R., Montero, J. R., \& Linz, J. J. (2002). Political parties: Old concepts and new challenges. New York: Oxford University Press. doi: 10.1093/0199246742.001.0001

HIDRA. (2005). Političke stranke u Republici Hrvatskoj. Zagreb: HIDRA.

Horowitz, D. (1985). Ethnic groups in conflict. Berkeley, Los Angeles, London: University of California Press.

Horowitz, J., \& Long, J. D. (2006). Democratic survival in multi-ethnic countries. Paper presented at the WGAPE Conference, April 2006. Pobrano 6 listopada 2014, z cega. berkeley.edu/assets/miscellaneous_files/wgape/10_Long.doc

Ishiyama, J., \& Breuning, M. (2011). What's in a name? Ethnic party identity and democratic development in post-communist politics. Party Politics, 17(2), 223-241. doi: $10.1177 / 1354068810391157$

Jackson Preece, J. (2007). Prawa mniejszości. Warszawa: Sic!

Judah, T. (2009). The Serbs: History, myth and destruction of Yugoslavia (3. wyd.). New Haven, London: Yale University Press.

Knežević, D. (2011). Srpska demokratska stranka od osnivanja do konstituiranja prvog višestranačkog Sabora. Časopis za suvremenu povijest, 43(1), 7-24.

Lijphart, A. (1977). Democracy in plural societies: A comparative exploration. New Haven: Yale University Press.

Lutovac, Z. (1996). Manjine, KEBS i jugoslavenska kriza. Beograd: Institut društvenih nauka i Institut za međunarodnu politiku i privredu.

Mikucka-Wójtowicz, D. (2010). The right to political representation for members of national minorities in the Republic of Croatia, 1990-2004. Sprawy Narodowościowe. Seria Nowa, (37), 7-17. 
Mikucka-Wójtowicz, D. (2013a). Działalność partii mniejszości narodowych w Republice Serbii w latach 1990-2008. Annales Academiae Paedagogicae Cracoviensis. Studia Politologica, XI, 87-112.

Mikucka-Wójtowicz, D. (2013b). Sytuacja mniejszości boszniackiej w Sandżaku - wyzwania i problemy. Sprawy Narodowościowe. Seria Nowa, (42), 143-167.

Müller-Rommel, F. (1998). Ethnoregionalist parties in Western Europe: Theoretical considerations and framework of analysis. W L. de Winter \& H. Türsan (Red.), Regionalist parties in Western Europe (ss. 17-27). London, New York: Routledge.

Nielsen, F. (1985). Toward a theory of ethnic solidarity in modern societies. American Sociological Review, 50(2), 133-149. doi: 10.2307/2095405

Oetere, S. (2010). Mniejszości pomiędzy segregacją, integracją i asymilacją: o powstaniu i rozwoju modelu autonomii kulturowej. Pobrano 5 kwietnia 2014, z http://www.haus. $\mathrm{pl} / \mathrm{pl} / \mathrm{pdf} / \mathrm{pub} 1 / \mathrm{SOeter} . \mathrm{pdf}$

Offe, C. (1999). Drogi transformacji: doświadczenia wschodnioeuropejskie i wschodnioniemieckie. Warszawa, Kraków: PWN.

Pal, Š. (1995). Koncept manjinske samouprave DZVM. Rad priložen na medjunarodnom naučnom skupu: Položaj manjina u SR Jugoslaviji, 11-13. januar 1995. Pobrano 15 lipca 2010, z http://www.vmdk.org/content/hu/koncman.html

Pal, Š. (2007). Globalizacija i manjine. Saopštenje sa naučnog skupa Multikulturalizam - pokretač i kočnica preduzetništva, Bečej, 26. april 2007. godine. Pobrano 15 lipca 2010, z http://www.vmdk.org/content/hu/vmdk168.html

Petsto stranaka otišlo u istoriju. (2010, maj 21). Danas. Pobrano 4 kwietnia 2014, z http://www.danas.rs/danasrs/politika/petsto_stranaka_otislo_u_istoriju.56.html?news_ id $=190747$

Popis stanovništva Republike Hrvatske 2001. (b.d.). Pobrano 4 kwietnia 2014, z www. dzs.hr

Popis stanovništva Republike Hrvatske 2011. (b.d.). Pobrano 4 kwietnia 2014, z www. dzs.hr

Popis stanovništva Republike Srbije 2002. (2002). Beograd: Republički zavod za statistiku. Pobrano 4 kwietnia 2014, z www.webrzs.statserb.sr.gov.yu/axd/dokumenti/ sn31122002.pdf

Popis stanovništva Republike Srbije 2011. (2011). Pobrano 4 kwietnia 2014, z www.popis2011.stat.rs

Rabushka, A., \& Shepsle, K. (1972). Politics in plural societies: A theory in democratic instability. Colombus, Ohio: Charles E. Merrill Publishing Company.

Samardžić, M. (1999). Položaj manjina u Vojvodini (drugo izmnjenjeno izdanje). Beograd: Centar za antiratnu akciju.

Samostalna demokratska srpska stranka [SDSS].(2005). Program.

Srpska demokratska stranka [SDS]. (1990a). Ciklus tribina Izbori u Hrvatskoj. W D. Đurić i in. (Red.), Stranke u Hrvatskoj. Dokumenti (ss. 339-341). Zagreb: Radničke novine.

Srpska demokratska stranka [SDS]. (1990b). Osnovna načela. W D. Đurić i in. (Red.), Stranke u Hrvatskoj. Dokumenti (ss. 335-339). Zagreb: Radničke novine.

Srpska narodna stranka [SNS]. (1997). Programska načela 1994. W A. Milardović (Red.), Političke stranke u Republici Hrvatskoj (ss. 261-265). Osijek-Zagreb-Split: Pan Liber.

Strmiska, M. (2002). A study on conceptualization of (ethno)regional parties. Central European Political Studies Review, 4(2-3). Pobrano 4 kwietnia 2014, z http://www.cepsr. com/clanek.php? ID =40 
Strmiska, M. (2003). Conceptualization and typology of European regional parties. Central European Political Studies Review, 5(2-3). Pobrano 5 kwietnia 2014, z http://www. cepsr.com/clanek.php?ID=167

Taleski, D. (2011). Competition between ethnic parties in a post-conflict context: Albanian parties in Macedonia and Serbian parties in Croatia. Paper presented at $61^{\text {st }}$ political Studies Associaton Annual Conference, London, 19-21 April 2011. Pobrano 4 kwietnia 2014, z http://academos.ro/sites/default/files/biblio-docs/102/929_461_0.pdf

Türsan, H. (1998). Introduction. Ethnoregionalist parties as an ethnic entrepreneurs. W L. de Winter \& H. Türsan (Red.), Regionalist parties in Western Europe (ss. 1-16). London, New York: Routledge.

Ustav Republike Srbije od 30.09 2006. (2006). Službeni glasnik Republike Srbije, (98(06)).

Ustavni zakon o pravima nacionalnih manjina. (2002). Narodne novine Republike Hrvatske, (155(02)).

Vukomanović, D. (2010). Obnova partijskog pluralizma u Srbiji krajem XX veka. Beograd: Institut za političke studije.

Zakon o političkim strankama. (2009). Službeni glasnik Republike Srbije, (36/09).

Zakošek, N. (2002). Politički sustav Hrvatske. Zagreb: FPZ.

Zuber, C. I. (2013). Beyond outbidding? Ethnic party strategies in Serbia. Party Politics, 19(5), 758-777, originally published online on 25 July 2011, doi: 10.1177/1354068811410368 